\title{
El reino chanca
}

RECIBIDO: 16/09/2017

APROBADO: 16/10/2017

Waldemar Espinoza Soriano

Universidad Nacional Mayor de San Marcos

<waldemar_espinozas@hotmail.com >

\section{RESUMEN}

Etnia de las más notables del antiguo Perú. Apareció después de la caída del imperio Wari. En seguida de largas emigraciones se estableció en el territorio de Andahuaylas en los Andes centrales. Allí puso en orden su señorío o apocuracazgo entre los siglos XI y xII. Dividido en Anansaya y Urinsaya, adquirió tanto poder que pensó en anexsarse otras etnias. Fracasó en su intento al ser derrotado por los incas del Cusco en la década de 1430. Prosiguió como wamani del Tahuantinsuyo y luego como corregimiento del virreinato. Persiste hasta hoy con la categoría de provincia del departamento y región Apurímac.

Palabras clave: Cacicazgo o señorío; Pacarina; Migración; Dualidad; Regiones; Pueblos; Ayllus; Topografia; Climas; Agro; Cultura material y espiritual.

\section{The Chanca Kingdom}

\section{ABSTRACT}

Ethnicity of the most remarkable of the old Peru. It appeared after the fall of the Wari empire. Soon after long migrations settled in the territory of Andahuaylas in the central Andes. There he ordered his lordship or apocuracazgo between the eleventh and twelfth centuries. Divided in Anansaya and Urinsaya, he acquired so much power that he thought of annexing other ethnic groups. It failed in its attempt to be defeated by the Incas of Cusco in the decade of 1430. It continued like Wamani of the Tahuantinsuyo and soon like corregimiento of the virreinato. It persists until today with the category of province of the department and Apurimac region.

KeYwords: Cacicazgo or señorío; Pacarine; Migration; Duality; Regions; Towns; Ayllus; Topography; Climates; Agro; Material and spiritual culture. 


\section{Los chancas}

$\square$ n el año 1548, por orden del clérigo don Pedro de La Gasca, se hizo la segunda visita del señorío Chanca, cuya trascripción de los puntos más importantes aparece en la no tan larga provisión de depósito de encomienda concedida a Diego de Maldonado el Rico, vecino del Cusco. Contiene los topónimos realmente completos de sus pueblos, aldeas y patronímicos de sus curacas. El cronista Gutiérrez de Santa Clara ya habla de la existencia del «pueblo de Andahuailas» en plenas guerras civiles de Gonzalo Pizarro (1550, I: 186). Después agrega "provincia de Andaguaylas", señorío de chancas (Ibíd 1550, III: 211). En este asentamiento, por ser bajo, no nevaba, pero sí en las alturas de la misma etnia.

Calvete de Estrella la titula asiento, a 40 leguas del Cusco y a cinco de la cuesta de Lucanas-Andamarcas (1567; 299-300, 361-362, 404).

"Provincia de Uranmarca» la titula Antonio de Vega (1600: 89). Estaba a siete leguas al sur de Vilcas, orillando el camino real. En esta distancia se atravesaba el río Vilcas, llamado así por estar cerca de estos aposentos. Tenía su puente de bejucos. En los aposentos de Uranmarca vivían mitmas solamente (Cieza 1553: 436). Iguales informes encontramos en el Inca Garcilaso (1609, V: 175).

Otro autor específica: "Los chancas, que es la nación que poseía el valle de Andahuaylas» (Acosta 1590: 200), dividida en dos mitades: Anan y Lurin (Guaman Poma 1615: 1073 [1083]). «Provincia principal, treinta leguas del Cusco, que se llama Andahuaylas» escribe Las Casas (1561: 655). Andahuaylas «es otra provincia» anota Pedro

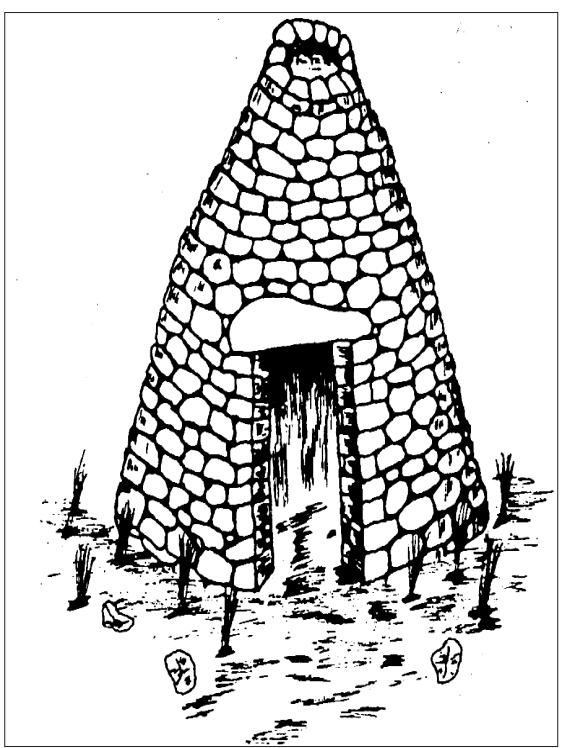

Casa chanca con techumbre lítica de forma cónica. Casa chanca. Nótese la forma del techo y el dintel (Proande). extremo belicosa (1609: 135). Anca Úallo Chanca o Anco-Uallo es como le designa Guaman Poma (1615: 85, 293-294), denominación que la usa en el mismo sentido Pachacuti Yanqui (1613: 239). Vázquez de (1630: 509-1479). El valle de Andahuaylas estaba muy bien proveído de bastimentos agro-alimenticios, razón por la cual la consideraban importante para la guerra (López de G.1552: 270). Era el quinto valle más bello del Tahuantinsuyo (Cobo 1653, II: 71).

La provincia de Andahuaylas comenzaba donde acababa los dominios del señorío Tanquigua. Seguía 31 leguas y terminaba en el río y puente de Pachachaca, entre el tambo de Cochacajas y el pueblo de Abancay, perteneciente éste al señorío Quichua o Quechua. Su clima en lo principal es cálido; pero tiene comarcas frías y otras templadas, conforme a las alturas y hondonadas hechas por la naturaleza. Produce maíz, papas y legumbres, frutas y buenos pastos. Al pie del pueblo de Andahuaylas pasa un arroyo que suele traer grandes avenidas en el verano, causantes de algunos daños. En esa parte carecía de puentes. Además, por el norte de su territorio corría un río navegable que le servía de foso y muralla con las etnias de la selva de la otra banda: es el Apurímac (Anónimo 1700?: 241). Espinosa se limita a formular "provincia y nación»
Pizarro (1571: 221). "Provincia de los Chancas» le nombra Gregorio de Cisneros (1597: 90). «Provincia de Andahuaylas» prorrumpe Antonio de Vega (1600: 89). «Naciones ... de Chancas y Hancohuallu» pergeña. Garcilaso de la Vega, el que le asigna de 16 a 17 leguas de espacio, dándoles el adjetivo de gente rica y en

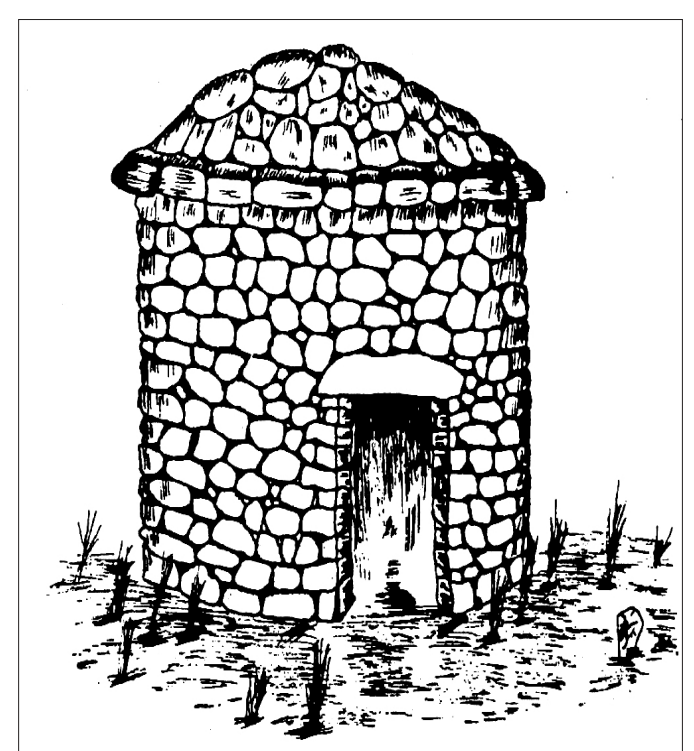

La palabra chanca tiene varias acepciones. Un lingüista especialista en lenguas andinas (Urbano 2008) ha descubierto que es una palabra de diversa pronunciación y significado, lo que dificulta la interpretación de esta onomástica. Un cronista dice que "por allá arriba» llaman Chancas a las que en el 
Cusco les dicen conopas o huasicamas, propiamente sus dioses lares o penates guardianes de las casas familiares. Las hacían de piedra en forma humana y de diversos colores y tamaños. Todo producto agrícola tenía su conopa trasmitida por herencia entre los sucesores o parientes.

Oliva es más claro: en el septentrión, expone, son conopas, en el Cusco son chancas, dioses lares o penates al que también denominan Huasicamayoc: mayordomo o dueño de la casa. Son ídolos de diversas materias y figuras, aunque de ordinario de algunas piedras particulares y pequeñas que exhibían algo de singular o notable en el color y figura. Lo reverencian y mochan con gran delizadeza para que mediante su favor y amparo tuvieran muchas cosechas y descanso. Las heredan de padres a hijos, aunque el preferido era el hijo mayor de la unidad doméstica; las vestían como a muñequitas (1631: 134-135). Los chancas o amuletos recibían veneración y adoración, y hasta sugerían e insinuaban para que otros hicieran lo mismo (Del Prado,1613: 194). Chanca es "poleo", es enmarañado, y otro lado: ajado. Chanca es por igual el cascajo, la graba y gofio o harina gruesa de maíz: cazabe, relacionado con chanca, o sea, machacado, triturado. Chanca es asimismo postre de chuño, veleidad y capricho, machacado y triturado, pierna, muslo (Urbano 2008: 217). Es sugerente como entre los varios nombres que daban al dios ordenador Apo Con Ticsi Wirakuchan, uno de ellos es Chanca Wiracuchan (Molina 1575: 48).

Empero, Chanca -o cunchur- constituia la palabra que más usaban para indicar a los idolillos de piedra nombrados conopas, es decir amuletos, que los evangelizadores de los siglos XVI y XVII solían semejarlas a los penates o lares de los antiguos romanos (Arriaga 1621: 35 / Avendaño 1649: 147). Era de propiedad familiar, por lo que lo guardaban en el interior de sus chozas, pudiendo transferirlo como herencia. Lo consideraban un pequeño oráculo para comunicarse con los dioses mayores llamados Apu o Jircas o Wamanis que moraban en el interior de las cumbres principalmente cubiertas con nieve. Para lograr esto lo lanzaban al cerro, como si arrojaran dados. Según la señal interpretaban el significado, pero siempre terminaban llorando como acostumbraban en sus actividades rituales. Le hacían sacrificios para alcanzar y/o conservar la buena salud, las excelentes cosechas, la abundancia de ganado (Annua de 1571. Polía 1999: 199).
La palabra Chanca. Como se vio, es una onomástica runashimi, que vertida al castellano es tambien muslo o pierna entera o cuarto de pierna; pero al posponerle $z a p a, n i, o$ zzanzzani significa persona que camina bamboleándose o temblando y hasta saltando $(\mathrm{GH}$ 1608: 94). También existe en aymara con el significado de hilo de fibra de camélido y de otras cosas (Bertonio 1612: 1a Pte $265 / 2^{\text {a }}$ Pte 77). En el primer caso se trata de una exonimia impuesta no como sobrenombre glorioso, sino un hilarante apodo endilgado por los opositores.

La huaca Auqui-Chanca, de los Huachus y mitmas Yauyos en Chocorvos simbolizaría "pierna del principal»; si hubieran pronunciado chancaauqui querían decir "príncipe chanca o del país de los chancas». Cuniavillca, su hijo, sería cerro ardiente, o más propiamente "cerro colorado" (Del Prado 1613:183).

Saliendo del Cusco, antes de llegar al país Chanca o ya dentro de él, un cronista enumera una serie de naciones que, es increíble que pudiesen haber tenido esta categoría. Son Tacmara, Quinualla, Curampa y Cochacassa - donde un Inca mandó hacer un gran depósito-, que fueron conquistados con gran facilidad por ser de poca gente. Luego menciona «la gran provincia de Antahuaylla» (Garcilaso 1609: 135). Aquí se percibe otra confusión del cronista cusqueño, ya que las cuatro primeras poblaciones a las que alude, concretamente formaron parte del señorío Chanca en condición de curacazgos menores o secundarios. En cuanto a Andahuaylas no hay sospecha que fue la capital del, alguna vez, poderoso señorío Chanca, tan venido a menos ulteriormente de ser derrotados por los incas.

El mismo cronista Garcilaso sostiene que se componía de "diversas naciones», entre ellas Hancohuallu, Utunsulla, Uramarca, Uillca y otras, cada cual jactanciosas por proceder de distintos prestigiosos ancestros o pacarinas: manantiales, lagunas, colinas altas, cavernas etc. Cada «nación» de éstas tenía por dios a los que adoraron sus padres con ofrendas y sacrificios (1609: 135). Lo que dio motivo para que no pocos historiadores del siglo xx imaginaran que conformaron una gigantesca federación, aglutinando naciones desde Vilcashuamán, Chalcos y Soras, hasta Andahuaylas; e incluso Ancara. Fue una fiebre que atribuía filiación Chanca a todo vestigio de ceramica en dicho ámbito. Por cierto que tales elucubraciones emanaban no de la historia mítica incaica, sino de las páginas fabuladas 
por Garcilaso de la Vega. Ancoayllu o Ancohuallo fue el curaca de Lurinchanca en la época de Pachacutec, y nada más.

Sulla y Utunsulla — según Garcilaso- fueron dos "provincias» al poniente de Vilcas, hacia la costa, de inmensa población, en cuyos territorios existían otras muchas «naciones de diversos nombres, unas de mucha gente y otras de poca", con un total de 40.000 vecinos. Los incas los conquistaron después de largos meses de escaramuzas, pero al fin los redujo. Tenían minas de plata y azogue (1609: 136). Aquí hay exageración, se trata de recuerdos o de imaginaciones mezclados referentes a comarcas internas de otros curacazgos desperdigados. Al hablar de vetas de azogue está remitiéndonos al señorío Ancara (Huancavelica), y al escribir de Utunsulla, se refiere a Atunsulla, espacio que es mencionado por López de Velasco, al hablar de las minas de oro, plata y cobre en el señorío Chocorvo (1630, II: 74-75). Bien que existía otro Atunsulla, menos notable que, durante la colonia, fue convertido en estancia ganadera del distrito de Totos en la provincia de Tanquigua o Cangallo, a 3.918 msnm (Stiglich 1922: 124). En un distinto folio de los Comentarios reales aparecen, como aliadas de los chancas las «naciones» Hanchohualu (Ancohuallu), Uramarca, Uillca y Untunsulla (Garcilaso 1609: 175). No se ha ubicado ni demostrado la efectividad de la etnia y "provincia de Sulla». Enseguida repasemos acontecimientos más concretos de la historia mítica forjada, archivada y sustentada por los propios chancas.

Su pacarina o punto de su origen político-social, lo fijaron ellos mismos en el lago de Choclococha, de donde afirmaban haber emergido sus primeros ancestros, lago ubicado en el señorío de Chocorvos (Chucurpu/Castrovirreina), del cual, siendo ya numerosos, salieron y se desplazaron poco a poco hasta esblecerse en Andahuaylas (Antaguailla). Tal aseveración anuncia que no se sentían oriundos de la referida provincia de Andahuaylas. A similitud de Lambayeque, Chimu e Incas conservaban la memoria de haber venido de fuera, de muy lejos. Consecuentemente, de conformidad a su singular historia legendaria no se originaron ni evolucionaron en Antahuayla. A ésta arribaron ya transformados y adelantados, con ambiciones guerreristas de expansión y dominio territorial. Es el concepto que aceptaron para no desdibujar lo que ellos pensaban y creían, incentivados por las narraciones de sus antepasados.
Como etnia con identidad propia ya existía desde antes de los incas, se forjó luego de la caída del Imperio Wari o Huari ( $c f r$ Montesinos 1642: 20, 23, 24). El señorío Chanca, efectivamente, hace su aparición ulteriormente de la desestruturación del imperio Wari, en el siglo XI d. C. Según sus propias tradiciones, procedían de las alturas de Chucurpu (Chocorvos / Castrovirreina actual, a suroeste de Huancavelica), pues situaban su pacarina o lugar de origen en el lago de Choclococha, a 4.950 metros sobre el nivel del mar. A dicho palude lo sacralizaron, teniéndolo por improfanable, lo consideraban su templo principal para sus adoraciones y sacrificios (Cieza 1553: 436). Sin embargo, también hay otro cronista que añade ser descendientes del feroz puma, por lo que lo reverenciaban y rendían pleitesía y hasta lo ostentaban como divisa; en su bien calendarizadas festividades más solemnes e importantes. Se vestían con las pieles de tan fiero felino para mostrar bravosidad (Garcilaso 1609: 135 / Repetido por Vásquez de Espinosa 1630: 74).

De modo que es incierto el dato dejado por Garcilaso en el sentido que los chancas se gloriaban de descender de un puma o león americano, al cual lo adoraban antes de comenzar sus grandes festejos rituales, ideología que lo materializaban disfrazándose 24 de ellos de felinos, ocasiones en la que los hombres se cubrían con el pellejo y metían su cabeza en la del puma. Escena que el mismo Garcilaso lo presenció en la fiesta el Santísimo Sacramento en el Cusco (1609: 135). La primera parte de este informe debe ser el producto de la interpretación del citado autor, ya que en el antiguo Perú no existió la idea del tótem o animal progenitor. Pero la segunda parte no, por cuanto asegura haber presenciado dicha coreografía, muy común en el espacio andino.

Lo hiperbólico del mito es que salieron de la citada laguna «mil millones» de chancas, aparte de mujeres, viejos y niños. Su apocuraca ya era Anca Uallo que tuvo el propósito de ser Inca, cuya vida cronológicamente coincidió con la de Manco Capac, primer gran señor del Cusco, quien le presentó y donó a su hermana Topa Uaco para sellar una alianza intercambiando esposas; pero esta mujer guerrera sin ocultar su condición de Uarmi-Auca (mujer guerrera, ¿lesbiana?), engañó y asesinó al caudillo y capitán Anca Uallo (Guaman Poma 1615: 85). ¿Cómo descifrar este informe? $1^{\circ}$ Que la población chanca fue numerosa; $2^{\circ}$ que constituyó una etnia con pretensiones imperiales por considerarse vinculada al precedente Estado 
Huari; $3^{\circ}$ que cronologicamente coincidiría con el desplazamiento de los primeros incas al Cusco; $4^{\circ}$ que chancas e incas fueron naciones fuertes, que llegarona intercambiar esposas para limar enfrentamientos, bien que dicho plan fracasó por ser la mujer cusqueña un instrumento para desaparecer al jefe chanca.

De acuerdo a los caudillos que los dirigían, rememoraban a Uscovlca de Anan Chanca y a Ancovilva de Lurin Chanca; aunque que es verdad que a su ejército lo tenían organizado en tres divisiones, lo que anuncia que entre ellos funcionaba la dualidad en la vida social y la tripartición en las actividades guerreras.

Tuvieron muchos combates con etnias comarcanas, todas ganadas por ellos, adueñándose pasajeramente de más curacazgos alejados de su centro nuclear (Las Casas 1561: CCL-655).

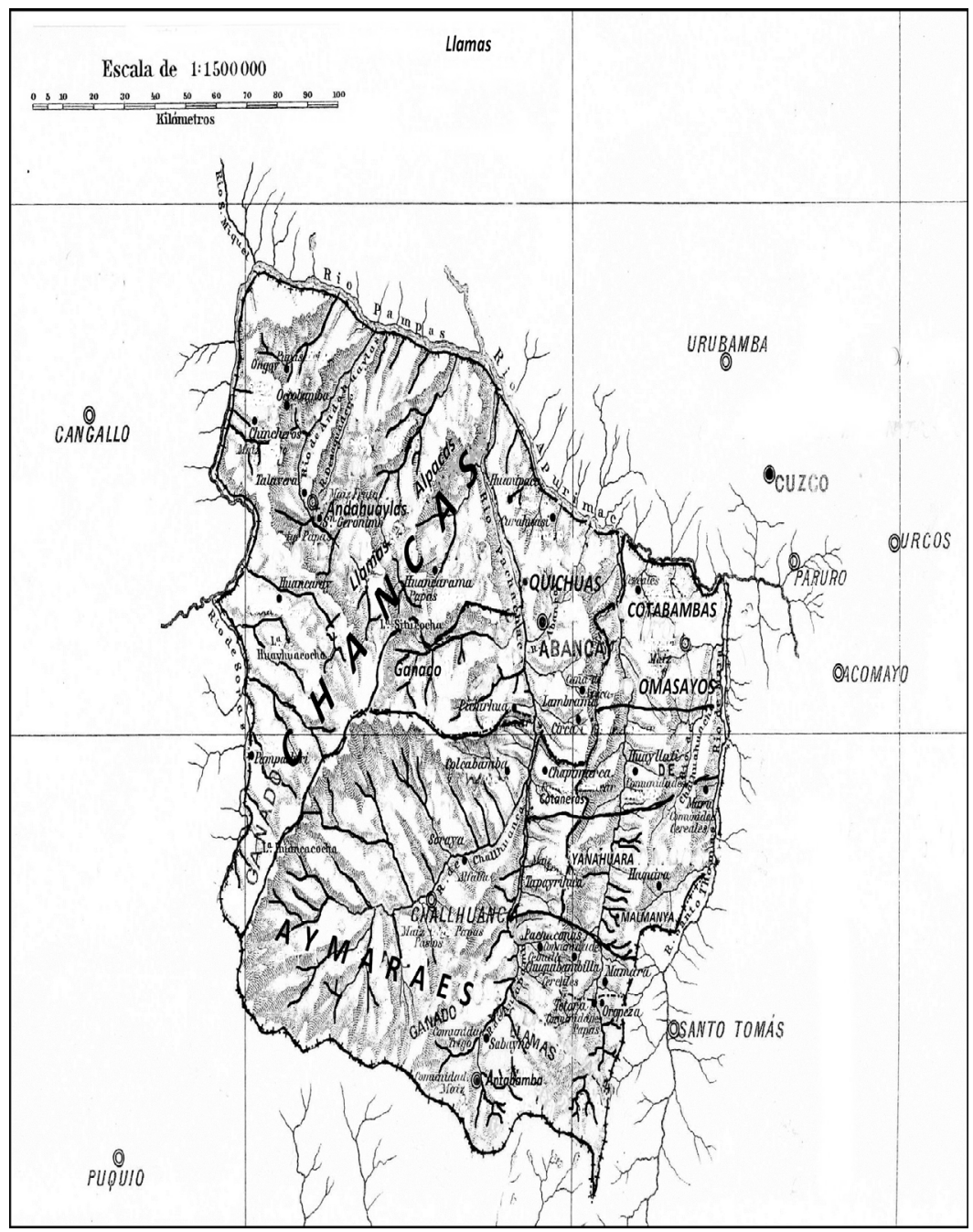

Localizacion de los señorios chanca, quichua, aymaraes, cotanera, omasayo y yanahuara.
De allí, estos aguerridos pastores de altura de habla quechua, obligados por alteraciones climáticas $\mathrm{y}$ aspiraciones políticas se vieron forzados a salir y migrar multitudinariamente siguiendo el curso de las aguas del río Pampas, comandados por dos capitanes: Asto Huaraca y Apo Huayco, jefes de cada una de sus mitades o sayas duales.

Se desplazaron llevando todos lo que pudieron: semillas, ganado y enseres, es que ya no pensaban retornar. Pasaron por Paucaray o Paucara, un asentamiento frío en una sierra flanqueada por intrincados roquedales, ubicado a tres leguas de Parcos (18 kilómetros) al sur de Acobamba del señorío Ancara. Ahí pararon mucho tiempo, pues allí nació y creció el líder que iba a llevar el mismo nombre de su principal deidad: Uscovilca, quien, maduro ya, iba a ser el fundador del poderío Chanca (Betanzos 1551).

Llegó la fecha que todos partieron de Paucaray, La gente de esta etnia tenía conciencia de constituir una de las grandes naciones, un Estado con poder. Por eso —en Paucaray mismo - el jefe Usco Vilca, adulto ya, reunió a sus guerreadores para planificar la campaña e instauración del Estado Chanca ( $c f r$ Betanzos 1551: VI, $\mathrm{X}$ ), cuando los grupos incas estaban administrados por Huiracocha. Indudablemente fue un pueblo guerrero, muy valeroso en su tiempo. Salieron para conquistar muchas naciones, buscaban nuevas tierras para fundar y poblar con el objetivo de eternizar su nombre. Cuando arribaron a la entonces dilatada provincia de Andahuaylas, poblada por la extensa nación Quichua, la invadieron y conquistaron; por ser de buen clima y de tierras fértiles para la agricultura y ganadería, asentaron allí su habitación. (Sin imaginarse que iban a ser derrotados algún día del futuro en Ichumanba), prosiguieron hasta que por fin encontraron el suelo y los microclimas que anhelaban en un paraje nombrado Chuquipampa, en el que establecieron su asiento, pero con la intención de seguir avanzando ( $c f r$ Cieza 1554 a: 192-193). Como se ve, escogieron un espacio relativamente cercano al valle del Cusco, donde la etnia Inca iba en camino con miras a la formación de otro Estado conquistador (Vázquez de Espinosa 1630: 509).

Se posesionaron, pues, de gran parte del perímetro occidental del seńorío Quichua, nación muy antigua, para lo cual tuvieron que pelear y descalabrar a los antiguos ayllus con quienes chocaron allí. Los Anan y Lurin Quichuas, al percatarse de las consecuencias que se les venía encima, se pusieron a punto de combate. Decididos unánimemente concluyeron sobre lo justo 
de resistir con beligerancia hasta dar muerte a quienes asaltaban sus territorios. Salieron por una abra rumbo a la sureńa etnia Aymara. En tanto los mismos chancas también se acercaban a ellos. Una vez frente a frente sus dirigentes dialogaron algunas veces sin lograr avenencia alguna. El corolario fue una denodada batalla. La victoria parecía no alcanzarla el uno ni el otro, pero al final los quechuas fueron derrocados por completo y los cautivos tratados con crueldad, pues dejaban sin vida a todo quien caía en sus manos, sin perdonar a criaturas, nińos, ancianos ni inválidos.

Capturaron a las mujeres quichuas para convertirlas en sus criadas y cónyuges secundarias. Así los chancas se enseñorearon de más de la mitad del país Quichua, poniéndolo bajo su dominio ( $c f r$ Cieza 1554 a: 192193) hasta la época de Pachacutec, quien les consintió como dueńos y señores de la espaciosa provincia de Andahuaylas. Como se advierte los chancas ganaron por fuerza de las armas, echando, arrinconando y estrechando a los antiguos pobladores quechuas al este de su provincia; les quitaron muchos terrales, hasta les constriñeron a que les dieran mitayos; los trataban cual conquistadores tiranos (Garcilaso 1609: 135). Tales acaecimientos debieron iniciarse entre fines del siglo XII y comienzos del XIII, en las décadas contemporáneas a la derrota de los puquinas y desplazamiento de los incas de Taipicala rumbo al Cusco; pero la invasión de los chancas al señorío Quichua, tal como lo acabamos de ver, fue enseguida del regicidio de Yahuar Huacac y cuando ejercía el mando el tristemente célebre Inca Urcon (cfr Cieza 1554 a: 192-193). A todo esto hay que aceptarlo como hechos acaecidos, y no totalmente mitológicos como han propugnado ciertos estudiosos.

Ya en la provincia de Andahuayllas, los chancas aparecen solidamente comandados por un par de caudillos guerreros, tipo sinchis o jefes militares que se consideraban hermanos, uno y otro caracterizados por su bizarría y decisión conquistadora. Tenían por nombre Uscouilca y Ancouilca que, después de haber cruzado por Quinua (Guamanga), Chalco y Sora se apoderaron del valle de Andahuayllas. Uscouilca, de mayor rango, estaba considerado como el jefe principal. Reordenaron sus sayas o mitades (parcialidades), la primera denominada Ananchanca siguió bajo la jefatura de Uscouilca, mientras que Ancouilca continuó manejando a los Lurinchanca: es decir, los chancas de arriba y los chancas de abajo. Pero éstos murieron y sus cadáveres embalsamados; por haber sido muy invencibles y muy acatados, los ananchacas y lurinchancas convirtieron a sus cuerpos disecados en bultos divinizados, verdaderos íconos para transportarlos consigo en las campañas presentes y futuras. La fuerza de su pensamiento atribuía a esas momias el triunfo en sus expediciones. Por sobrenombre a Ancouilca le pusieron Ancoallo (Sarmiento 1572: 231). Sus sucesores prosiguieron poniéndose sus apelativos.

Ciertos datos sostienen que los chancas confiaban en el oráculo de Huancarrama, al noreste de su territorio; huaca que sostuvo alguna vez, que Inca Roca no era el verdadero señor del Cusco, pese a lo cual venció con facilidad a varios curacas en sus propias tierras, entre ellos a los de Huancarama y Andahuaylas (Montesinos 1642, XVIII: 82).

Los chancas dejados por Uscuvilca en la provincia de Andahuaylas, ya en los tiempos de Huiracocha Inca, habían aumentado de manera cuantiosa, al punto de reputarse invictos, sin parangón en el mundo (andino). Por eso determinaron proyectarse más allá; dentro de esas miras estaba muy bien calculada la invasión y captura del Cusco. Para esto eligieron dos sinchis: Astoguaraca y Tomayguaraca, el primero de Anan y el otro de Urin para que se desempeñaran en dicha empresa y jornada. Así las cosas, los valientes guerreros se pusieron en marcha al Cusco, hasta introducirse en la llanura de Ichupampa, cinco leguas al oeste de la gran llacta. Ahí permanecieron algunos días atemorizando la comarca y ultimando las tácticas de la espectacular invasión al Cusco (Sarmiento 1572: 231.232).

Aquí es el momento de aclarar como ha habido intenciones de alterar la geografía de los Chancas. No se sabe qué interés movió a algunos para atribuirles capciosa y erróneamente la posesión y control de las etnias o provincias que en su tiempo estuvieron en lo que ahora son los departamentos de Apurimac, Ayacucho y Huancavelica ( $v g r$ Garcilaso 1609: lib IV, cap. 15. Lib V, cap XIX). Todo lo cual es una falsedad redonda. Felizmente otro cronista, lejos de las pasiones y muy cercano a la objetividad si logró recoger lo verídico, atribuyéndoles únicamente la provincia de Andahuaylas (Cobo 1653, II: 73). A Garcilaso le han repetido y/o copiado docenas de escritores. Éste lo hizo con el propósito de magnificar en número a los chancas, opositores del curacazgo del Cusco que, por entonces, configuraba un pequeño señorío o capaccuracazgo. Como éstos — de poca gente - vencieron en los enfrentamientos, quedaron enaltecidos por su audacia y heroicidad favorecida, decían, por la ayuda 
del Con Ticsi Wirakuchan o el Sol. Inventaron mitos para intercalarlos en la verdadera historia oficial incaica, con su correspondiente propaganda y difusión que perdura hasta hoy.

Aquí la parte más importante de sus nuevas posesiones es que estaban en Andahuaylas y Vilcaparo. En la primera continuaron divididos en dos mitades: Anan y Lurin. Allí se organizaron en 56 pueblos, dos de ellos quichuas de Vilcaparo (Huarillane y Tororo). La Chanca aparece como provincia fraccionada en Anan y Rurin (Lurin), cada una con su capital y cacique mayor, esas cabeceras tenían por nombre Layohuacho (ahora San Pedro de Andahuaylas) y el segundo Pomahuacho (San Jerónimo y Talavera). Su población ascendía a muchos millares de habitantes, que vivían en una provincia muy ensanchada con muchos pastos para la crianza de bastante ganado doméstico y silvestre. Sus poblaciones y caseríos aparecían bastante diseminados.

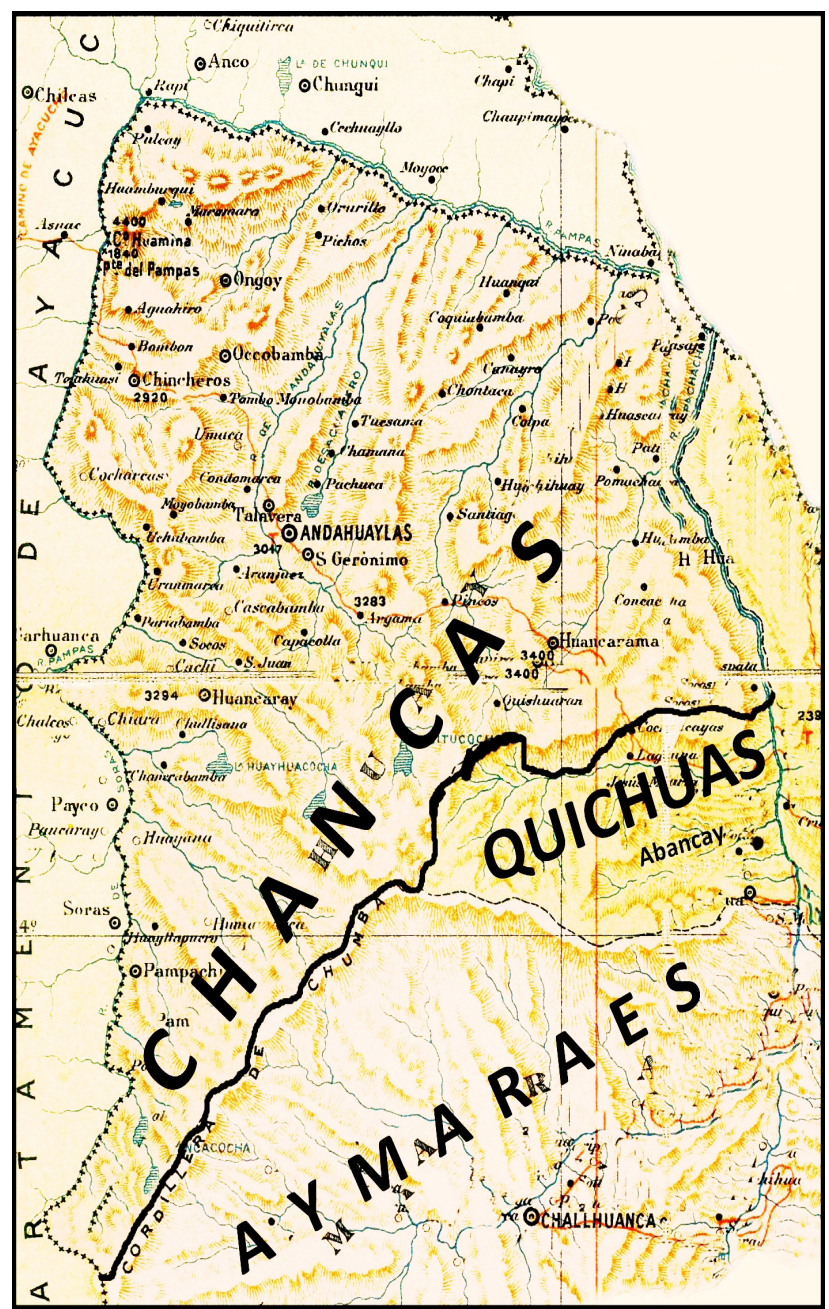

El señorîo chanca, ubicado al norte de los señorios quichua y aymaraes, ahora región apurimac.
Pocas demarcaciones geográficas del mundo andino tienen un cúmulo de condiciones favorables que la han hecho famosa. Como aserto de su antigüedad están los lugares epónimos de Curamba, Huancarama, Uranmarca y Suntur, en lo principal él último, cuya existencia se remonta a épocas anteriores a los incas, sin que éstos la hayan abandonado en ningún momento durante el Tahuantinsuyo. En segundo lugar, es zona agrícola de gran potencialidad, sobre todo para los tubérculos. La provincia permanece encerrada por una parte en los tres lados de un cuadrilátero fluvial, por cuyo cuarto lado es una subcordillera fría, situada allí como para darle a la provincia todos los climas deseables, desde los más suaves a los más rigurosos: un paraíso de microclimas. De manera que nada le faltaba de lo deseable. La llacta misma de Andahuaylas, tan mentada en los anales chancas, es de excelente clima que jamás llega a hacerse rígido en invierno ni sofocante en el verano, en una situación pintoresca a $3.017 \mathrm{msnm}$, es tan hermosa y florida que abunda de frutos y otros recursos para la vida. Nada les faltaba por allí. Llueve bastante en las temporadas de aguas (Calvete 1567, IV: 7 / Stiglich 1922: 50). En lo que incumbe a los andenes de Curamba ahora se sabe que fueron construcciones especialmente para fundir y obtener plomo no argentífero durante el incario, manufacturando piezas como vasos por ejemplo. Hay ausencia de huayras y tocochimbos y de minerales de menas de plata en el sitio (Brooks 2012: 204-206).

Tiene quebradas amplias, muy largas y sanas donde jamás caen heladas. A 12 kilómetros está la laguna de Pacucha, un lugar de los mayores encantos de la naturaleza. Poseía la cantidad suficiente de habitantes, sin la penuria de necesitar ninguna otra gente para su constante funcionamiento agrícola $y$ ganadero y para cualquier otra artesanía por grande y difícil que hubiese sido. Los pastos de Pampachiri, en la margen derecha del río Soras, gozaban de prestigio por brindar inverna abundante para llamas y alpacas. Pampachiri, al sur de la etnia, quedaba a dos días de camino para arribar a Andahuaylas. En los ríos Pampas, Pachachaca y Apurimac tenían el suficiente caudal de aguas para soportar, de bajada, la navegación en balsas, fácil para contactarse con los pueblos extranjeros del norte. Además, de los tres ríos caudalosos que la vivifican, el país Chanca gozaba de otros no menos importantes, como el Soras, uno de los brazos principales del Pampas; también el Andahuaylas, que forma el delicioso, florido y hermoso 
valle, pocos lugares reúnen tantos embelesos como éste donde se alza la moderna ciudad. El Quishuarani es el río más alejado de los centros poblados. Aparte, posee quebradas amplias, muy largas y sanas por donde jamás hay heladas. Sus aldeas y caseríos estaban convenientemente diseminados. El ramal de los Andes que penetra en Andahuaylas alcanza hasta las bocas del Pachachaca y del Pampas; y es el mismo que desprende otras cadenas de cerros de menor importancia, aunque si lo suficiente elevadas como para impedir el fácil despegue del territorio oriental de Andahuaylas, por lo que los cálidos valles cercanos a los grandes ríos solo eran atendidos por unidades domésticas. Huancarama, ubicada al este, era una zona muy habitada, entre el Pampas y el Pachachaca, comprende sublimes quebradas tributarias de uno y otro. Ongoy se ubica al norte del país Chanca y al sur del Pampas en el rodeo que hace cuando va rumbo norte-este. Es dueña de la importante quebrada de Ongoy, que desciende del Huamburqui y cae al Pampas, aunque propensa al paludismo, sus sementeras de papas se perdían por las heladas, distaba 11 leguas de Andahuaylas. Vale también mencionar a Chincheros, ubicado en la parte más occidental de Andahuaylas, con moradores muy entendidos en la construcción de puentes colgantes. El del río Pampas, en este sitio es antíquísimo, de tránsito obligado para los caminantes por el capacñan de los incas. Dicho puente era como la puerta de control entre Andahuaylas y Sora. Chincheros tenía terrenos muy fértiles, pero castigados por las heladas; su clima cálido en las hondonadas enfermizas permitía el cultivo de frutas y ají. Estaba a 11 leguas de Andahuaylas (Paz Soldán 1877 / Stiglich 1922: 50, 156, 204, 325).

Existían minas de oro en Huallarripa, de las más renombradas del Perú (Palomino 1549, ii: 9).

Por ser una de las naciones más guerreras, sus centros poblados, aunque muy diseminados, los erigieron en sitios reputados por ellos estratégicos, es decir, en las alturas y laderas de la cordillera. Salvo el lugar de Andahuaylas, en el que si dieron pasó a una llacta. Sentían mucha atracción por las construcciones circulares techadas con bóveda falsa y de varillas que sostenían techumbre de paja-ichu; y menos por las cuadrangulares y rectangulares, todas con muros de piedra y barro modelo pirca, con cercos defensivos. Para determinados edificios utilizaban piedras seleccionadas que dan apariencia homogénea a las superficies de las paredes exteriores e interiores. Los restos que subsisten no muestras inmuebles que sugieran haber sido templos ni barrios residenciales de elite. Por el contrario, la integridad exhibe a una sociedad parigual o indistinta. Su cerámica es burda, técnicamente poco perfeccionada. Sus herramientas agrícolas, de molienda, raspadores, lascas y armas son de piedra; usaban cuchillos de obsidiana o quishpi. (González Carré 2002: 546-547).

A las cinco reparticiones internas de la nación Quechua, y a otras vecinas, las tenían rendidas, comportándose ante ellas con dureza y tiranía ( $c f$. Garcilaso, 1609, lib. IV: 145).

En general la etnia Chanca comprendía 16 populosos ayllus divididos en dos sayas: Anan y Rurin o Urin, habitaban por lo menos en 56 aldeas nativas, o sea solamente de chancas. Los Anan-Chanca con su cabecera en Andahuaylas, fundada por Uscovilca; en tanto los Lurin-Chancas con su cabecera en Uranmarca, fundada por Ancovilca (Sarmiento 1572: 163 ed 1943).

Otros pueblos chancas eran Utunsulla; mientras que Chalcumarca y Suramarca fueron fortalezas de Anco Huallo en Andahuaylas, famoso general (Vázquez de E. 1630: 510-1481).

Se ha conservado el listado de los 16 clanes y de sus 62 centros poblados, pero los dos documentos examinados no permitan enumerarlos por sayas o mitades, por separado. Veámoslo en orden como quedó conformada la wamani o provincia Chanca durante las postrimerías del imperio de los Incas:

$1^{\circ}$ Chuquicondor-Lapa, señor el pueblo de Layohuacho. 2o Lombo, señor del pueblo de Pomahuacho. $3^{\circ}$ Condor-Suca, señor del pueblo de Guamanilla. $4^{\circ}$ Asto, señor del pueblo de Zapacalla. $5^{\circ}$ LLacta-Conas, señor del pueblo de Ongoro. $6^{\circ}$ Guasco, señor del pueblo de Bambamarca. $7^{\circ}$ Guncho, señor del pueblo de Quevilla. 80 Sulcaguaman, señor del pueblo de Cacacha. 9o Tomay Nampa, señor del pueblo de Chuayapo. 10 Maras Guama, señor del pueblo de Caquesamarca, es inga. $11^{\circ}$ Orozo, señor del pueblo de Guayaconil, [es] chachapoya. $12^{\circ}$ Pacovilca, señor del pueblo de Pacocha. $13^{\circ}$ Yanas, señor del pueblo de Guatara. $14^{\circ}$ Chontaya, señor del pueblo de Orcomalca. $15^{\circ}$ Allauca, señor del pueblo de Yslana. $16^{\circ}$ Coyca e otro Mayma, seńores del pueblo de Pocollo, son quichuas. 170 Guaman Vilca, señor del pueblo de Gualguayo. 18 Tubanaypa, señor del pueblo de Cochabamba. $19^{\circ}$ Alcailla, señor del pueblo de Chuquibamba. $20^{\circ}$ Chochuma, señor del pueblo de Guarillone, son quichuas. 21ㅇ Abaca, señor del pueblo 
de Cocas, son yungas. 220 Cancache, señor del pueblo de Sillueque. 23 Canas, señor del pueblo de Yanama. $24^{\circ}$ Ynda, señor de Todoro, son quichuas. $25^{\circ} \mathrm{Nava}$ Hastu, señor del pueblo de Aymayba. 26 Suca, señor del pueblo de Chuchumbe. $27^{\circ}$ Guamanlaya, señor del pueblo de Bambamalca. 28 Guaraca, señor del pueblo de Chocpalla. 29० Guasco, señor del pueblo de Queca. 30a Quilli Changas, señor del pueblo de LLamay. 31 Muyacondor, señor del pueblo de Chupuisguacho. $32^{\circ}$ Guachaca, señor del pueblo del pueblo de Pupuca. $33^{\circ}$ Magula, señor del pueblo de Pomachaca. 34 Curatomay y Tomay Condor, señores del pueblo de Nidaba $35^{\circ}$ Lengare, señor del pueblo de Quenoavilca. $36^{\circ}$ Queque Hasto, señor del pueblo de Laracalla. $37^{\circ}$ LLacaguabeis, señor del pueblo de Opibacho. $38^{\circ}$ Guascopachua, señor del pueblo de Tulpo. 39 Chuquillapas, señor del pueblo de Midaquechua. 40 Ala, señor del pueblo de Ococho. 410 Quiquimalca, señor del pueblo de Tiquillo. 42० Maqui, señor del pueblo de Maguey- Camalla. 43 Quichuy, señor del pueblo de Cachi. 44 Viscasana, señor del pueblo de Chiliceni. $45^{\circ}$ Sulla, señor del pueblo de Capatcalla. $46^{\circ}$ Chocollo, señor del pueblo de Cola. 470 Larcho (?), señor del pueblo de Chuquillampa. $48^{\circ}$ Qulencha, señor del pueblo de Aychica. 49 Suca, señor del pueblo de Chiara. $50^{\circ}$ Guachovilca, señor del pueblo de Paracaya. $51^{\circ}$ Chueco, señor del pueblo de Chacana. $52^{\circ}$ Hasto y Lapa, señores del pueblo de Loroya. $53^{\circ}$ Changa Guasco, señor del pueblo de Suya. 54 Curasica señor del pueblo de Yanapisco (Yanapillo?). 55० Guacharondo y Magula, seńores del pueblo de Chumbichallanga. $56^{\circ}$ Chuquicamaca, señor del pueblo de Guayana. 570 Paucar, señor del pueblo de Omamaca, son orejones. $58^{\circ}$ Caluacuri y Sevmda, señores del pueblo de Vilcabamba. 590 Moygua, señor del pueblo de Apcara, es orejón. $60^{\circ}$ Aocasibi, señor del pueblo de Chuca, es orejón. $61^{\circ}$ Guachaca, señor del pueblo de Aymaras, «son mytimaes de los aymaras que se dice soso». $62^{\circ}$ Chauca Quiyaruyo y Tucuyrico, Hurcoguaranga, es orejón, señores del pueblo de Moyomarca y Chabilbamba (Francisco Pizarro. Cusco, 15-IV-1539. Provisión de depósito. AGI. P-93).

Con todo, la fuente anterior no contiene información completa. Omiten a la "parcialidad de los Caxamarcas», mitmas reubicados en la comarca de Cocharcas, a 40 leguas del Cusco y a 20 de Quinua (Huamanga). Tales caxamarcas estaban administrados por el curaca Chuquisulca. Precisamente Sebastián Quimichi, hijo de Lope Martín y Luisa Asto, pertenecientes a este ayllu, fue quien introdujo en el pequeño pueblo de Cocharcas el culto a la Virgen de Copacabana (Montesinos 1642, II: 138).

Conocemos los nombres de sus ayllus agrupados en Anan y Lurin, pero es todavía imposible saber cuáles de esos centros poblados catalogados anteriormente pertenecerían a cada mitad. En una relativamente tardía revisita de 1604, después de más de 32 años de las reducciones toledanas que causó una enorme dispersion de unidades domésticas para concentrarlas en pocos pueblos, y cuando el atuncuraca principal de toda la provincia y de la parcialidad de Anansaya, era don Apo León Guasco; mientras que don Luis Tomay Guaraca era ansimismo cacique principal de la parcialidad de Urinsaya»; aparte de "otros muchos caciques y mandones e indios destos pueblos sujetos a los susodichos», lo que vale decir, curacas de ayllus y muchos mandones. Por entonces Anansaya, carecía de segunda-persona, solo tenía un curaca principal don León Apo Guasco, por título otorgado por el virrey don Luis de Velasco, y por ser sucesor en el cargo de su padre legítimo don Diego Guasco. El resultao fue el siguiente:

A). Parcialidad de Anansaya Chancas: $1^{\circ}$ Ayllu Guasco, con sus unidades domésticas repartidas en San Pedro de Andahuaylas y en todos los demás pueblos de la provincia. Por entonces su cacique don Lázaro Cóndor Guacho, con título del virrey don Luis de Velasco, había muerto hacía cuatro meses. Por no haber dejado hijos legítimos, sino apenas a uno de sus abuelos, don Carlos Tupa Guassco, residente en el pueblo de San Jerónimo, que tenía hijos legítimos mayores y aptos para la sucesión, de 25 años de edad y habilidades: don Jerónimo Tapa Guasco, don Francisco Guana Guasco y don Juan Guanacuasco, $y$ otros cuatro hijos menores de 20 años. El que gobernaba este ayllu entonces era don Diego Auqui Guasco, hijo legítimo de don Lázaro, cacique difunto. $2^{\circ}$ Ayllu Malma, a cargo de su cacique don Martín Acua Malma Viera, que paraba libremente en el pueblo de San Pedro de Andahuaylas, lo cual, afirmaban, lo aceptaba el virrey marqués de Cañete. $3^{\circ}$ Ayllu Moros, del cacique don Diego Guachorondo, hijo legítimo de don Luis Guachorondo, que fue cacique por título del virrey don Luis de Velasco. $4^{\circ}$ Ayllu Pachacarua del curaca don Pablo Quiquin Carbas, ya viejo, por lo que el cargo lo ejercía un hijo legítimo suyo por título del virrey marqués de Cañete. $5^{\circ}$ Ayllu Abras, del cacique 
don Felipe Tiquilla Cuntor, sobrino del difunto don Felipe Penaupas, que lo fue. Lo poseía por título del virrey don Luis de Velasco. $6^{\circ}$ Ayllu Inga o Ingale, del cacique don Diego Sibi Paucar, «de la dicha parcialidad de Hanansaya». Estaba ya anciano, pero con un hijo legítimo para sucederle. Lo poseía por título del virrey don Martín Enríquez. Unas veces le llaman Inca y otras Incale. ¿Son palabras pertenecientes a la cultura chanca neta, o acaso tenían algo que ver con ciertos mitmas procedentes del Cusco? $7^{\circ}$ Ayllu Chinchaysuyo, con el cacicazgo vacante por fallecimiento del titular don Juan Capcha Guaman. Este dejó un hijo legítimo y homónimo, de 30 años de edad. Gosaba de la aceptación de todos los caciques principales de los demás ayllus para otorgarle el titulo respectivo, pues tenía habilidad para ser curaca de ayllu. En este caso también hay que hacer la misma pregunta anterior, por cuanto Chinchaysuyo era una etnia al oeste del Cusco, ¿serían mitmas? $8^{\circ}$ Ayllu Yunga, a cargo del cacique don Pedro Islache por muerte de don Martín Islache. La sucesión directa y legal le correspondía a don Juan Islache. Pero erar menor de 20 años, edad que ya lo habilitaba para tomar el cargo legítimamente.

B). Parcialidad de Lurinsaya Chancas. A cargo, toda ella, del curaca principal don Luis Tomay Guaraca Tenía los ayllus siguientes: $1^{\circ}$ Ayllu Guaraca con su curava el mencinado don Luis Tomay Guaraca por título del marqués de Cañete, y sucesión legítima de su difunto tío don Cristóbal Chanca Tomay Guaraca. $2^{\circ}$ Ayllu Guachaca, don Juan Alca, menor, hijo legítimo de su homónimo el difunto don Juan Alca, más o menos de edad de 12 años, por lo que en su reemplazo ejercía don Luis (Tomay Guanaca) por título del virrey don Luis de Velasco expedido en 1601. $3^{\circ}$ Ayllu Yanas del difunto curaca don Pedro Nabin Asto. Debía sucederle un hermano suyo, legíimo, don Grabiel Nabin Asto, de 14 a 15 años de edad, quien en efecto debía gobernar cuando alcanzazara su mayoría; mientras tanto lo haría un cacique-gobernador interino, don Andrés Aycagualca, con autorización del corregidor. $4^{\circ}$ Ayllu Capac-Asto, del que fue curaca don Antonio Asto ya difunto. Su hijo legítimo llamado también don Antonio Asto, de 15 años de edad. Por su minoría fue designado cacique-gobernador don Luis Guasco por titulo el virrey don Luis de Velasco. $5^{\circ}$ Ayllu Matma a cargo del curacaca don Gaspar Auquirima, ya viejo y con hijo legítimo nombrado don Marcos Auquirima, de 30 ańos de edad, a quien le ayudaba a gobernar su padre. $6^{\circ}$ Ayllu Anta-Quichua, a cargo del curaca don Juan Asto. Por su muerte gobernó su hijo don Lázaro que asimismo murió; quedó su hijo legítimo, menor de 12 ańos llamado don Juan Capa. Por lo tanto, en el ínter, gobernaba su tío Felipe Asto Caquia, sin título del corregidor ni del virrey. En el pueblo de Turpa se desempeñaba como gobernador de este ayllu de Anta-Quichua don Baltasar Caquia Guarca por provisión del virrey don Luis de Velasco, aunque don Felipe era sobre todo el gobernador. $7^{\circ}$ Ayllu Vilcaporo, tuvo como cacique a don Diego Cayca, que murió dejando dos hijos legítimos que le sucedieron, el mayor don Juan Apyca de 26 años de edad, inhábil para gobernar, en cambio el otro, don Francisco Coyo, ya con los requisitos para asumir el cargo, conforme lo manifestaron los otros curacas de ayllus. $8^{\circ}$ Ayllu Yunga, del que era cacique don Francisco Yacha Are, pero sin título del corregidor ni del virrey, pese a reunir los requisitos de ley, entre ellos haber sido hijo legítimo de su padre don Francisco Yacha (Agustín Arce de Quiroz 1604. Visita de la provincia de Andahuaylas (AR.Cusco).

La presente nomenclatura muestra como los componentes de la etnia Chanca estaban localizados al este del Pampas; divididos en dos mitades o sayas: Todos estos asentamientos humanos paraban distribuidos en dos sayas o mitades: Anan y Urin. Los datos que han sobrevivido permiten señalar cuáles conformaban cada sector. Sabemos que los atuncuracas de Anan Chanca eran los Apo Guasco con mando en toda la provincia, mientras que el principalazgo de Urinsaya estaba en poder de los Tomay Huaraca con mando solo en su respectiva mitad. El ayllu Guasco ocupaba el primer rango, ya que siempre empezaban los censos o empadronamientos por él. Hubo ayllus que vivían en punas frías, como las de Pampachiri (con los ayllus Anta y Mayo); y otros en los valles de clima más benigno, como en Talavera y San Jerónimo de Cazama o Casania (Arce de Quiroz: 1604: 42r - 42v, 48r. ARC. Cusco).

Los chancas de los valles ocupaban San Pedro de Andahuaylas, San Jerónimo de Casania, La Asunción de Talavera, Andarapa, Cascabamba: de clima yunga o templado, estaba muy poblado y tenía prestigio por ser extraordinariamente maicero. Fue la razón para que en 1560 se prohibiese que fueran a mitar a las frías minas de Atunsulla (o Xunsulla) que, si bien de clima sano, de todas maneras difiere de los anteriores. Les permitieron, sin embargo, poder viajar para trocar 
sus productos (Polo de Ondegardo 1561: 459). El valle de Andahuaylas, de clima templado, favorecia la abundancia de maizales; pobladísimo de habitantes y de camélidos (Lizárraga 1605: 533).

Los chancas de las punas vivían en San Cristóbal de Pampachiri, Santiago de Guayana, La Concepción de Cachi, Santiago de Huancaray, Uripa, Ongoy, Guancarama, Ocobamba y Cayara -y posiblemente Chinchero- En la jurisdicción de Cachi estaban los terrenos de Tanquigua, con 48 habitantes, en el anexo de Chillisana. También se visitó a "los indios chancas» mitmas del repartimiento o provincia de de Huanta (Parixa).

En Andahuayla la nación chanca alcanzó gran extensión territorial y enorme población, adquirió más renombre y notabilidad. Su prestigio se calibra porque, aparte de su capac o rey, tenía sus capitanes o jefes de guerra celebérrimos por su valor: Mallma, Rapa, Yanavilca, Teclovilca, Guaman Huaraca, y Tomay Huaraca. El rey era Usco Vilca (Betanzos 1551: cap. VI), que jugaron roles decisivos en la restauración del imperio de los Incas.

Tan amplio territorio con numerosos asientos poblados, por decisión de sus jefes y necesidad de todos se comunicaban entre unos y otros. Para eso adquirieron un gran conocimiento práctico, una experiencia a toda prueba, para abrir senderos y trochas. Citaremos un ejemplo: la vía de Andahuaylas a Chincheros, de 10 leguas y de un día para su recorrido; a Pumacahuanca, 12 leguas también en un día de caminata; a Ninabamba, siete leguas en un día de viaje; y al navegable Apurimac, 10 leguas en un día de trote (Carlos Fry 1889, II: 86).

Los chancas disfrutaban de un enclave de coca en el cálido valle de Mayocmarca (o Mayonmarca o Mayun-Marca, en la región Antisuyo) al este de Quinua (Huamanga), en tierra yunga de cocales, es decir, cálida y húmeda, unida al señorío de Quinua gracias a un camino tan excelente que tenía la categoría de capac-ñan (Mendoza 1552: 197r passim / Guaman Poma 1615: 902, 1074 (1084). Hasta allí, cruzando el río Vilcas, caminaban los chancas, con la categoría de advenizos o mitmas, a sembrar, cuidar y coger hojas de coca (División del obispado del Cuzco. 1614. AGI. E-C 503 / AGL. A V: 13). De ahí la sacaban encestada para llevarla a sus pueblos. En el mismo perímetro estaban los cocales de Sintihuayla, pero a estos no tenían acceso los chancas, pertenecía por entero a los de Quinua (cf. Ribera de Chávez 1586; 110). No se sabe si el enclave de Mayocmarca es de data preinca, o si éstos les permitieron; pero lo cierto es que de dicho cocal les fue despojado por el corregidor de Huamanga, agregándolo a su territorio en calidad de anexo, so pretexto de estar más cerca a él. Lo administraba designando un teniente de corregidor (López de C. 1630: II: 73 / También en A 1: 264). En la colonia le cambiaron de nombre, llamándole Anco, al cual - para llegar - se hacía preciso el desplazamiento de 20 leguas caminando por la provincia de Huanta (120 kilómetros). En dicho valle poco a poco se erigieron cinco pueblos: Anco, Anchihuay, Rapi, Chinquintilca y Chunguy, los cuales — si bien de temple fríogozaban de frutos de la selva por tener sus habitantes algunas heredades en ella. Por entonces ya no solo cultivaban coca, sino cańa de azúcar, plátanos, paltas, chirimoyas, guayabas, piñas, naranjas, limones, maíz y algunas hortalizas. Su terreno fértil también servía de hábitat a víboras, culebras y alacranes, cosa común en la montaña. El nombre de Mayocmarca lo conservó hasta fines del siglo Xvir. Se cuenta que sus habitantes se retiraron a otros pueblos ahuyentados por los jaguares (Bueno 1767: 70).

Es un error de ciertos autores que propugnan que el dominio Chanca abarcó los que ahora son los departamentos de Huancavelica, Ayacucho y parte del de Apurimac. Hasta se ha inventado la categoría "Confederación Chanca». Se han habituado a considerar e identificar como Chanca a toda cerámica tecnológicamente pobre recogida en dichos departamentos. Producto de este furor es una incontable cantidad de «sitios chancas» desde Angaraes a Andahuaylas (González Carré 1979, 1992). Es un lapsus que debe acabar, porque en los espacios de tales circunscripciones departamentales, por entonces, florecían otras etnias, entre ellas la Chanca, Huachu, Chocorvo. Parixa o Parisha, Quinua, Tanquigua, Chalco-Soras, Lucanas, etc.

Son territorios que, con anterioridad, habían pertenecido a la zona nuclear del Imperio Wari, al que los mismos antepasados de los chancas pertenecieron, pero es evidente que destruido dicho Estado, no supieron aprovechar todos los adelantos científicos y tecnológicos, por eso no han dejado llactas grandes ni chicas bien planificadas, tampoco aposentos palaciegos, ni barrios residenciales. Sus pequeños asentamientos urbanos las más de las veces dispersos, ubicados en las faldas y cimas de los cerros, denuncian el estado de beligerancia permanente, pero no internamente entre 
ellos mismos, sino preparados para rechazar cualquier agresión de las etnias colindantes. Tal fue el devenir cotidiano en el espacio andino durante el Intermedio Tardío.

Radicados en el territorio de la provincia de Andahuaylas, poco a poco se organizaron, hasta que Uscovilca y otros adalides, entre éstos Ancovilca, conformaron un reino perfecto de acuerdo a los patrones económicos, sociales, políticos y religiosos andinos, heredados, no cabe porqué dudarlo, del destruido imperio Wari. Así por ejemplo, estaban configurados en dos mitades (Ananchanca y Lurinchanca), cada cual con su respectivo jefe o atuncuraca. Incluso conservaban los nombres de los caudillos que los guiaron en su peregrinaje o emigración: Uscovilca, líder de Ananchanca, y Ancovilca, de Urinchanca: representantes de una diarquía guerrera y política de origen divino. A los cadáveres de sus fundadores los guardaban momificados, cual oráculos y protectores de su nación, por eso las conducían en andas en la totalidad de sus expediciones.

En Andahuaylas racionalizaron admirablemente su vida con un hábil control de los pisos ecológicos, desde los bajos y cálidos valles interandinos hasta las frías punas de las alturas. Inclusive alcanzaron a tener enclaves de cocales en la selva (López de C. 1630). En su nuevo hábitat montaron todo un Estado, cuyo territorio lo ensanchaban por los cuatro puntos cardinales en forma incesante mediante invasiones y conquistas con tanto éxito como de la etnia Inca afincada en el Cusco. Posteriormente, en sus expediciones guerreras llevaban consigo el cuerpo disecado de su caudillo Uscovilca. Los chancas nunca olvidaron el nombre de siete adalides suyos, gracias a cuya táctica y estrategia dilataron sus posesiones en diferentes períodos: $1^{\circ}$ Mallma y Rapa, que incursionaron por el oeste de Condesuyo; $2^{\circ}$ Yanavilca y Teclovilca, que invadieron el Antisuyo, $3^{\circ}$ Tomay Huaraca y Astohuaraca, que atacaron el Cusco; y $4^{\circ}$ Huamán Huaraca, que negoció la cobarde rendición del inca Huiracocha y de su hijo Urcon.

Sus productos son fáciles de descubrir al leer la tasa tributaria anual de 1552, firmada por fray Jerónimo de Loayza por encargo de La Gasca, prácticamente la primera que les impuso el gobierno colonial. $1^{\circ}$ Seis mil pesos de oro de 450 maravedíes cada uno, o su equivalente en oro puro. $2^{\circ}$ Trecientos vestidos de lana, 150 de cumpi y 150 de awasca. $3^{\circ}$ Dos paños o reposteros de pared de 4 varas de caída y 5 de través;
6 cojines vacíos; 12 capotes; 50 costales con sus sogas; 12 mantas; una "algodonera» de 3 varas de largo y 2 de ancho, todo de lana; se trata de bolsas para coger y beneficiar el algodón, separado el vellón de la simiente (DRAE 1791: 53). $4^{\circ}$ Más 50 trajes de cumbi y 50 de awasca. $5^{\circ}$ Ocho arrobas de lana. $6^{\circ}$ Cien llamas, más 200 de ganado para comer. $7^{\circ}$ Doce arrobas de sebo. $8^{\circ}$ Ciento cincuenta pares de perdices al año. $9^{\circ} \mathrm{Un}$ arrelde de pescado por semana, salvo en cuaresma que debía ser de dos arreldes semanales. El arrelde contenía cuatro libras (DRAE: 99). $10^{\circ}$ Mil doscientas fanegas de maíz al año. $11^{\circ}$ Trecientas fanegas de papas al año. $12^{\circ}$ Cuatro fanegas de ají. $13^{\circ}$ Algunas frutas si la hubiere. $14^{\circ}$ Cuatrocientos pares de alpargatas al año de cabuya, más 100 de algodón, 50 costales con sus guascas, 50 sogas para lazos de cinco brazas cada una, y de jáquimas con sus cabestros y cinchas con sus látigos de cordeles y sueltas. De cada cosa de éstas 8 y 300 pares de ojotas. Todo de cabuya. $15^{\circ}$ De madera: 50 bateas anuales, las seis grandes y las demás pequeñas, más seis sillas. $16^{\circ}$ Tablas: 60 maderos anuales de 25 pies de largo cada una; 40 tablas de tres varas de largo. $17^{\circ}$ Veinticinco cargas de carbón al mes. $18^{\circ}$ Sesenta cestos de coca por cada mita, de las tres existentes al año. $19^{\circ}$ Ciento cincuenta fanegas de maíz y 30 de trIgo. $20^{\circ}$ Quince cargas de carbón. $21^{\circ}$ Tejas en cantidad según la necesidad del encomendero, con tierra dada en el Cusco, etc. (Mendoza 1552: 184-188). En esta tasa figuran cosas traídas e impuestas por los españoles para que aprendiesen los chancas: 267 aves de Castilla cada cuatro meses; 50 huevos semanales, si bien en Semana Santa, aumentaba a 120; 159 fanegas de trigo; 25 sirvientes cada que el encomendero estuviera en Andahuaylas; 30 trabajadores para la guarda de sus ganados. Llama la atención que no les impusieran tributos en coca, pues los chancas la cultivaban en sus chacras enclavadas en Mayocmarca en los Andes de Huanta (Ibid: 197r passim / Tasa autorizada por La Gasca. Lima, 30-X-1550. AGI. P - 93).

Ya se reportó que sus casas, como todas de la altura andinas, son de planta circular, paredes de piedra, pirca y techumbre cónica, de paja-ichu, con puertas muy bajas y angostas, carentes de ventanas, características de la totalidad de las casitas de altura del ámbito andino para defenderse de la frialdad nocturna (Cieza 1553: 436). Sus alfares no tienen nada de finura ni estética, como acontece en todas las etnias serranas de su tiempo.

$\mathrm{Su}$ peinado distintivo, exclusivo de los chancas, consistía en traer los cabellos largos entrenzados 
menudamente puestos unos cordones de lana que les venía a caer por debajo de la quijada (Cieza 1553: 436).

Sus danzas las ejecutaban en plazas hechas especialmente para eso. Vestían mantas y camisetas de lana. Sus funerales y enterramientos no diferían de las etnias colindantes. Creían en la inmortalidad del alma, a la que llamaban xoingon -shongo o songo: corazón(Cieza 1553: 436). A los cuerpos difuntos de sus curacas los enterraban con mujeres vivas y alguna ropa y tesoros. Un testigo ocular de lo que ocurrió al fallecer un curaca, cuenta que escogieron una mujer joven para que fuese al Upaymarca o mundo de las almas, con la finalidad de servirle, para eso le pusieron unas ollas pequeńas para puchero, cucharas, ají y otras cosas para hacerle sus alimenos. La vistieron muy bien a su modo; y cargada de pucheritos la llevaron a una peńa para despeñarla. Temerosa de hacerse mil pedazos, la arrojaron, pero cayó viva, salvo una herida no mortal en la frente (Cabredo 1600: 77-78).

Pese a tanto respeto por sus curacas, se sabe que, por lo menos una vez, envenenaron a uno de ellos, a instancias de los celos de una de sus mujeres ( $c f$. Cabredo 1600: 74). Los jefes practicaban la poliginia con hasta dos y tres esposas, a veces repudiaban a su mujer principal. Los chancas consultaban a adivinos, éstos les obligaban a comer carne cruda, beber sangre y propinar veneno para matar a los curacas, quienes en tal estado nombraban a su sucesor. Precisamente en cierta ocasión una shaman determinó dar muerte a un curaca chanca, impulsada por el ansía de que su marido entrase en su lugar a heredar el curacazgo. Llevó la ponzońa en la mano derecha para echarla en un vaso que portaba en la izquierda; pero turbándose cambió las manos y la dio a su marido que estaba destinado al curaca, y lo mató. No se detuvo en su intento dañino, y dio otro vaso al curaca, que también sucumbió (Cisneros 1597: 90-91, 92,94. / Vega 1600).

Los chancas tenían sus huacas propias. Sus divinidades principales eran dos: $\mathrm{I}^{\circ}$ En lugar preferencial, Uscovilca, perteneciente a Anan-Chanca. La representaban en una estatua de piedra a manera de hombre vestido con ropaja ornado con tocapus, un modelo propio de los chancas. Su santuario estaba en el pueblo de Andahuaylas. II $^{\circ}$ En segundo término, Ancovilca, huaca de Lurin-Chanca, también una efigie petrea en un templo respectivo; y al que acostumbraban conducirlo consigo por donde quiera que iban (Albornoz 1582: 28). Ambas efigies sustituían a sus cadáveres momificados.
Al parecer, tanto Uscovilca como Ancovilca, en figuras de menor tamańo, los colocaban en un altar casero, delante de un brasero en el que quemaban sebo; la sangre de los cuyes sacrificados la asperjaban por todo el aposento, acompañado con su bebida o chicha. Esta huaca tenía ganado en las punas, de su propiedad; muchas mujeres solteras se ocupaban en su servicio, hilando para ofrendarle. Acudían a reverenciarlo mucha gente. Era un ídolo heredado de padres a hijos (Cabredo 1600: 76-77).

Tenían sacerdotes y shamanes de ambos sexos, expertos en su oficio. Al fallecer lavaban al cuerpo yerto; lo velaban toda la noche, bebiendo lo conducían al entierro, vestido el difunto con ropa nueva, le ofrecían comida y cada ańo renovaban la misma ofrenda. A los cuerpos de sus progenitores los guardaban en cuevas y entierros antiguos. Les sacrificaban al iniciar el sembrío en sus chacras echando chicha en el suelo de la parcela. Al chispear creían que las almas de sus antepasados padecían sed y hambre; arrojaba maíz, papas, chicha y otras comidas en el fuego para que comieran y bebieran. En Huancaraimi el culto principal era a los muertos momificados o malquis. De este modo también sacrificaban durante las enfermedades. Adivinaban con cuyes y arañas (Luis de Teruel. En Arriaga 1621: 83-84).

Tenían adivinos, éstos les instaban a comer carne cruda, beber sangre de animales, reverenciar al Rayo. Adoraban al Sol, Luna y Estrellas, les ofrecían sacrificios de animales a nombre de sí y de parientas nacidas de píes, consideradas hijas del Rayo, por eso le ofrendaban a la criatura matando dos animales. Una mujer quitó la vida a tres criaturas por orden del sacerdote. Había féminas shamanas que curaban con harina de maíz y sangre de llamas que manaba por un costado; lo metían en un costalillo de harina para darle al enfermo en medio de oraciones especiales. En un pueblo chanca, castigado por un huayco que arrastró parte del poblado y luego cayó un Rayo que quemó un edificio, desde entonces no se acercaban al lugar siniestrado, abandonaban sus casas quienes sufrían este tipo de accidentes (Cabredo 1600: 70, 72-74).

También hay informes que hablan de las afamadas huacas llamadas Auqui-Chanca y su hijo Cuniavillca, conocidos y venerados en un circuito muy amplio: Chocorvos, Acoria, Sullcamarca, Córdoba, Carachapampa, Sancos y Lucanas, es decir, desde Chocorvos y Ancara a Lucanas. Venían a adorarlos desde remotísimos lugares, incluso del Cusco. Les 
hacían su fiesta en cuatro oportunidades al año, las cuatro con gran veneración y solemnidad, suntuosos regocijos y danzas, ritos y ceremonias. Una de aquellas festividades coincidía con la aparición en el firmamento del Hemisferio Sur, de la constelación de las Siete Cabrillas (Oncoy); otras en los días de Corpus Christi, Navidad y Semana Santa. Es que en el espacio andino, cada nación aseguraba tener su huaca principal llamado Cuncahuacas, cual patrón de los pobladores. Pero cada ayllu y parcialidad, adoraba a otras huacas particulares que le decian Ayllu-Huaca. Por su lado, cada jefe de familia o unidad doméstica, cual mayorazgo, poseía otras divinidades nombradas Chancas, Mayhuas, Canllamas, Ingas y Pichiges. Las heredaban por sucesión los primogénitos, quienes los entregaban a la hora de su muerte con muchas protestaciones (orden firme de ejecutar), exhortaciones y ceremonias (Del Prado 1613: 183 -184).

En el pueblo de Andahuaylas los Chanca sustentaban un oráculo (¿Uscovilca?) a cargo de sacerdotes y sacerdotisas, los cuales le interrogaban para recibir respuestas, a las que nadie negaba validez. Le pedían que vaticinara incluso quiénes iban a ser los ganadores de las batallas el mismo día del choque, aún a 200 y 300 leguas de distancia; contestaban inmediatamente. También predecían el porvenir de las personas (Gutiérrez de SC 1550, I: 332).

En la provincia de Conchucos, por donde fugaron 6.000 chancas a la selva, con la precipitación de la escapatoria, abandonaron a su huaca (Uscovilca?) un gran ídolo en figura de persona al que los conchucanos dieron el nombre de Chanca. Le dedicaron una niña de 14 años, edad admitida para casar a las chicas, en la presente situación la más hermosa nacida entre ellos, con quien decidieron matrimoniarla. La llevaron sus padres y curacas para efectuar la ceremonia del connubio entre la efigie y la niña. A la boda ritual concurrió la totalidad del pueblo con quien la desposaron celebrando la festividad durante tres días con grandes expectativas de sacrificios y consumo de chicha, bebida ceremonial y de prestigio por antonomasia. Por intermedio de la adolescente cónyuge ofrecían sus sacrificios, por considerar de gran suerte y estima hacerla a través de ella, por creerla más acepta a su divinidad. Por haber sido desposada con la huaca estaba obligada a guardar virginidad, realmente fue investida como sacerdotisa. La miraban con suma reverencia, superior y sagrada. Estaba sometida a muchas restricciones de tabú o prohibiciones (Arriaga
1621: 26, 36-37). Llegó a tan suprema estimación esta linda doncella, que por su mano ofrecían algún sacrificio, lo tenían por gran felicidad, considerándose bienaventurados, por estimar que configuraba el rito más propiciatorio y más acepto el realizado ante y a través de la consorte del dios Chanca. Guardaba perpetua castidad, así lo prometía ella misma el día del desposorio con el ídolo. La acataban y obedecían como a ministra de la citada divinidad, realmente quedaba con la investidura de sacerdotisa. La veneraban como a cosa divina (Calancha 1638: 473).

Otro rito conocido de los antiguos chancas lo realizaban en el interior de sus propias casas. Sacrificaban a un ídolo o huaca de piedra en figura humana, vestido con un tocapu, o mejor dicho, adornos pertenecientes a las vestiduras de los sapaiancas; asimismo llevaba un cuchullauto, propio igualmente de la cabeza de los señores incas, sin duda réplicas del bulto de Uscovilca. La figura estaba colocada en un altar y en su delante un bracero alimentado con sebo; derramaban la sangre de cuyes, asperjaban todo el aposento con chicha. Así llevaban a cabo su ritual. Para esa huaca tenían 300 carneros, y muchas mujeres solteras dedicadas a su servicio, quienes hilaban para su ídolo (Gregorio de Cisneros 1597: 95. En Antonio de Vega 1600). Contaban que en un pueblo de las alturas, súbitamente salió de debajo de un cerro un aluvión, arrasando parte de la población. Con un rayo se quemó su mejor huaca o edificio con todo lo que estaba adentro. De conformidad a sus creencias ya no debían volverla habitar, la tapiaron y empezaron a hacer otra construcción. Sucedió en un pueblo al que los extirpadores bautizaron con el nombre de San Francisco (Ibíd.: 93).

Finalmente, con respecto a sus creencias mágicoreligiosas hay más informes valiosos. Ya se expresó que rendían culto al Rayo, Sol, Luna y estrellas con sacrificios de animales no solo en beneficio propio sino en provecho de otros; hubo una mujer shaman que dio muerte a tres criaturas y a otra recién nacida de una de sus parientas. Lo hizo después de consultar con un chaman que le aseguró ser hija del Rayo, motivo por el cual le ofrecieron la criatura por medio de ella, inmolaron asimismo dos animales en medio de ritualidades específicas (Ibíd.: 90-91, 92,94).

En relación a capac-huchas se conoce cómo una muchacha, cuando se produjo la muerte de un curaca chanca, la escogieron para que fuese a la otra vida a servirle; por lo tanto debía llevarle unos chamillcos o 
chamelicos y cucharas con ají y otros productos para cocinarle y guisar sus alimentos. Vistieron a la moza muy bien, acompañándola de pucheros la llevaron a una peña a borde de un río, para despeñarla. Desde luego que las referidas muchachas a veces sentían mucho malestar ante estos sacrificios, al ver el peligro de la muerte ante los ojos, convencidas de terminar hechas pedazos. Se dice que alguna vez cayó viva una de ellas al fondo del precipicio, aunque lastimada en la frente hacia el ojo derecho (Ibíd.: 98).

Entre sus prácticas útiles sabían conservar la memoria de los sucesos empleando piedras (piedrezuelas), también con el recurso de cordeles y nudos de colores diferentes (quipus), en los que incluso conservaban el recuerdo biográfico de las obras y hechos de sus antepasados. Los pastores, mientras apacentaban a su ganado, con una piedra y un palillo en la mano refrescaban la retentiva de las oraciones aprendidas, aplicándose a este ejercicio con constancia y consuelo (Ibíd.: 93, 94-95).

El reino Chanca, por lo menos hasta 1438, año de su revés, participaba de estructuras sociales, políticas y económicas similares a las demás "naciones», incluso semejantes a las incas.

Sus instituciones políticas, la organización de sus guerreros no presentaban diferencias notorias al confrontarlas con las de los cuscos. Lo mismo podemos decir de sus estructuras ideológicas y técnicas de expansión y conquista, etcétera (Betanzos 1551: cap. $\mathrm{VI})$.

Los chancas, en las primeras décadas del siglo $\mathrm{XV}$, fecha en la que proyectaban y planificaban su expansionismo, se complacían de contento al conocer que todos los seńoríos y reinos ubicados en lo que ahora son los departamentos de Ayacucho y Apurímac, más el norte de Arequipa (Condesuyos), los reputaban como a decididos y valientes guerreros. En el lapso de 1430-1440 se preparaban para intervenir en los países de los ayarmacas y de los Incas, y enseguida lanzarse contra collas-puquinas, lupacas y demás etnias de localización intermedia. Por entonces los del Cusco estaban gobernados por Inca Urcon, si bien a éste continuamente lo asesoraba su decrépito padre Huiracocha, retirado en Calca.

Eligieron como capitán general a Ancohuallo, valeroso hombre, y por maeses de campo a los dos hermanos Tumay Huaraca y Asto Huaraca. Los demás curacas prosiguieron como caudillos y capitanes de sus parcialidades. A toda diligencia fueron en demanda de sus propósitos (cf. Garcilaso 1609: 145).

Esta vez los chancas avanzaron con fuerza hasta parar en la orilla izquierda del Apurímac, realizando sacrificios a sus divinidades para vencer. Su general Asto Huaraca los aguijoneaba para proseguir hasta culminar la alta empresa en la que se encontraban comprometidos, sin temblar ante nadie, y peor frente a esos incas del Cusco que pretendían espantar con sus orejas largas y mitos de origen divino. De vencerlos, obtendrían un opulento botín, además de cientos de mujeres hermosas con quien holgarse. Los guerreros chancas, emocionados por la oratoria de su jefe, solo atinaron a responder positivamente y con alegría (Cieza 1554 a: 219).

Los autores de esta expansión, los que realmente espoleaban, fueron tres curacas principales de tres grandes subdivisiones de la nación Chanca, debajo de cuyo nombre se incluían muchas sayas y mitades. $1^{\text {a }}$ Hancohuallo, mozo de 26 años; 2a Tumay Huaraca y $3^{\mathrm{a}}$ Asto Huaraca: una triarquira de dirigentes estrategas; los dos últimos hermanos y deudos del primero (Garcilaso 1609: 145). En las antiguas fortalezas chancas de Challcumarca y Uranmarca, es donde estuvo Hancohuallu los días postreros de su reinado (Ibíd.: 187-188).

La alta dirección militar chanca combinó sus expediciones en la siguiente forma: $1^{\circ} \mathrm{A}$ los jefes guerreros Mallma e Irapa, al mando de la tercera parte de los efectivos militares, los encaminó para que conquistaran las naciones del Condesuyo «hasta donde gente no hallasen que conquistar pudiese»; los alentó para el triunfo prometiéndoles plena libertad para apropiarse de los despojos y botines de la guerra. $2^{\circ} \mathrm{A}$ los capitanes Yanavilca y Ticliovilca, con la otra tercera porción de guerreros los enrumbó al Antisuyo con el encargo expreso de no pasar por el Cusco, sino a una distancia de 10 leguas de ella (50 kilómetros); es evidente ansiaba los pastizales, rebaños y cocales. $3^{\circ} \mathrm{El}$ supreno jefe Chanca, que se hacía llamar con el mismo nombre de su divinidad, meditaba reservar para sí la invasión y conquista de lo él consideraba la zona medular, acompañado con dos capitanes y los guerreros que sobraban. El corolario de tan gigantesca campaña, como se deja colegir, debía ser la constitución de un Estado a imagen y similitud del imperio Huari, pero ya no con este nominativo, sino el de imperio Chanca, con el gran capac Usco Vilca a la cabeza. Por lo visto, éste líder decidió pues capitanear 
él mismo, para obligar a Huiracocha a aceptar su capitulación, quien se preciaba de su poderío y gran desarrollo cultural (Betanzos 1551: 101, 103, 116117). Aunque tambien tenía sus miradas dirigidas al Collasuyo que, como las otras regiones, era extensa y rica, casi toda con más simpatía hacia el Cusco (c $f$. Gutiérrez SC 1550, III: 211).

Los triunfos de los dos primeros batallones fueron increíblemente espectaculares, pues lograron conquistar y anexar Condesuyos; avanzaron 50 leguas más allá de Charcas (300 kilómetros), es decir, hasta Chichas. Lo mismo sucedió con la segunda expedición, la cual invadió triunfalmente el Antisuyo, llegando victoriosamente hasta las fronteras de los chiriguanos. Así aseguraban las tradiciones y leyendas narradas por cusqueños y chancas en el siglo Xvi (Betanzos 1551: 116-117).

Usco Vilca, como es de esperar, emprendió su marcha y ataque al Cusco con la otra tercera fracción de su ejército. Al llegar al valle de Jaquijaguana, los habitantes de este lugar los aceptaron, y como muestra de su oferta adoptaron el peinado de los chancas, entrenzándose los cabellos. Lo demás son incidentes ampliamente conocidos. Pensaron que Cusco ya caía bajo su poder (ibid).

Las evidencias dejadas por los cronistas del siglo XVI, presentan al eximio guerrero y héroe Usco Vilca como un gran visionario chanca que ansiaba conquistar todos los reinos y seńoríos andinos para configurar un poderoso Estado imperial. Y desde este ángulo con más fortaleza que el de los incas, cuyo diminuto señorío, gobernado entonces por el débil Huiracocha y por su corrupto hijo Inca Urcon, no daba muestras de pretensiones expansionistas hasta ese momento (Espinoza Soriano 1987: cap. 3).

Por ir tan victoriosos y triunfantes estuvieron seguros y a punto de ganar la guerra y ser señores del futuro imperio andino, por cuanto desde su salida no perdían los combates y alianzas (Vázquez de Espinosa 1630: 509, 510).

El Cusco cayó ante los chancas comandados por Uscovilca. Pero la rendición no fue posterior a una derrota bélica, sino enseguida de un requerimiento de sumisión pacífica, preferida en los conquistadores andinos, hecha por el caudillo chanca por intermedio de una embajada. El inca Huiracocha se rindió y decidió ser vasallo de Uscovilca. Los chancas habían, pues, vencido, parecía que nadie sería ya capaz de resistir su poder y prestigio. Sin embargo, los ayllus del valle del Cusco, en especial los Inca, mientras los embajadores chancas retornaban llevando el mensaje a Uscovilca, decidieron ocultar su desacierto, retirándose al peñol de Jaquijaguana. De todas maneras les resultó penoso ver la entrada triunfal de los chancas al Cusco (Betanzos 1551: 104). Sin embargo, ahí fue cuando surgió la figura egregia del príncipe Inca Yupanqui (el futuro Pachacutec), que optó por libertar a su etnia ya rendida al vigor Chanca. Decidió combatir a sangre y fuego, hasta vencer o morir para reconquistarla. Excelentes colaboradores se aprestaron a ayudarle: Vica Quirao, Apo Mayta y Quilliscacha Urco Guaranga. Lo extraordinario fue que pudo convencer a los señoríos vecinos, ubicados a tres leguas a la redonda del Cusco (18 kilómetros) para que se plegaran a los incas en una lucha cuerpo a cuerpo contra el invasor y conquistador Chanca (Betanzos 1551: VI, VII). Hasta consiguieron la ayuda de los canas y canchis en calidad de alquilados o mercenarios; con éstos el príncipe aumentaba sus posibilidades de vencer (Ondegardo 1561: 132). Por fin llegó al Cusco el auxilio de por lo menos tres señoríos de la región Arequipa, uno de ellos los Yumina que, establecido ya el imperio, Pachacutec los elevó al estatus de incas de privilegio, con orejeras. El contraataque fue tremendo. Los victoriosos chancas resultaron desbaratados, en tanto que los desvalidos incas acabaron triunfantes. Pero la fortuna les fue adversa al enfrentarse con el príncipe, quien no solo frenó el expansionismo Chanca, sino que los destruyó para siempre con crueldad para los vencidos, hasta obligarlos a aceptar el vasallaje, aunque al final, después de visitarlos en sus provincias los hon ró restituyéndolos en sus estados (curacazgos), después de sus desdichas (Vázquez de E. 1630: 509,510-1479). El reino Chanca se desintegró, y volvió a ser lo que fue antes: un señorío, pero esta vez un señorío vasallo del imperio de los Incas que, justo, se constituyó gracias al fracaso chanca. Fue una gesta épica para ambos contrincantes. Usco Vilca, jefe de los Anan y autoridad suprema a de la etnia Chanca, fue tomado prisionero y muerto en la batalla del Cusco.

Los otros escuadrones chancas que habían obtenido tantos triunfos sobre los contisuyos, chichas y antisuyoschiriguanos, y que retornaban radiantes cargando los trofeos del éxito arrebatados a sus víctimas. Pero fueron avisados del desastre de sus colegas en la batalla del Cusco (Betanzos 1551: VII). Ni se imaginaban que pronto iban a ser vencidos totalmente en Ichubamba, situado en Condesuyos. 
Los chancas descalabrados por los incas en el llano de Omachilliguas, fugaron con tantísimo apuro que daban la impresión de haberse convertido en cóndores. Desde entonces los chancas recibieron el sobrenombre de condorguachos (Albornoz 1582: 26). Por lo tanto, no es nada raro que esta ave fuera una de sus protectores, por ellos venerada, aunque para los incas constituía una frase peyorativa, relacionada con la lujuria, la suciedad, las malas palabras y la deshonestidad en general $(\mathrm{GH}$ 1608: 55, 169). Con este suceso queda demostrado que en la ideología chanca, ellos tenían el poder de la licantropía, lo que vale decir, la omnipotencia de trasmutarse en aves, esta vez en vulturidas, para poner a salvo sus vidas.

Vencidos en tan brava y sanguinolenta colisión, el príncipe Pachacutec Capac Inca Yupanqui venció y prendió a los hermanos chancas, con muerte de muchos de los suyos. Y se hizo señor de los pueblos, entre ellos de la provincia de Andahuaylas; ajusticio a los mencionados hermanos; puso guarniciones en la tierra anexada, y enseguida volvió a la llacta del Cusco, donde fue recibido triunfalmente (Gutiérrez de SC 1550; III: 211). De los cráneos de sus enemigos muertos mandó hacer mates para beber (Murúa 1616. I: 48).

Después de descansar muchos días el inca en Andahuaylas, ordenó sepultar a los cadáveres para evitar que la podredumbre fomentara pestilencias y matara gente como en oportunidades anteriores. Dispuso sacrificios en homenaje a Wiracuchan y al Sol. Avisó a todos los gobernadores de la ventaja alcanzada sobre los contrincantes. Repartió el despojo entre sus soldados y decretó que en el Cusco se concentraran los curacas principales de los señoríos amigos para que viesen su entrada triunfal, con el justo premio y recompensa a los leales y castigo a los desleales. Las intenciones de los incas fueron tremebundas, no solo castigarlos, sino —más que todo- escarmentarlos bajándoles la moral y socavándoles todo rezago de autoestima que todavía les pudiera quedar.

La fiesta guerrera y ritual por este triunfo fue escalofriante. En lo tocante a la derrota Chanca existen informes espeluznantes. Acto seguido, luego de distribuir los despojos entre sus soldados, con la prevención que le caracterizaba, pensó que en el Cusco estarían ya esperándo los señores de las provincias vecinas, aguardando su ingreso triunfal, evento que ansiaban ver, sobre todo el premio dado a los leales y el castigo a los derrotados.
Poniendo en acción antiguos elementos culturales de las altas civilizaciones andinas, el inca no omitió nada. Con tal objetivo el gentío común chanca salió caminando delante, profiriendo a voces: i”Viva muchos años tan buen rey!». Seguían las trompetas de caracolas y los tambores grandes, dos instrumentos que solamente aparecían para ser oídos mezclados a esos clamores populares. Apenas dejaban de tocar de cuando en cuando para que la gente oyese aquellos griteríos que se acaban de citar. De inmediato 2.000 soldados en orden de combate con sus respectivos capitanes e insignias oficiales de sus jerarquías. Iban gloriosamente engalanados con las cabezas muy adornadas, opulentos tocados y placas como medallas en los pechos, relucían con muchas plumas de diversos colores; tratándose de los jefes portaban enormes patenas de oro en los pechos y espaldas. Mientras que los soldados las traían de plata, metal habido entre los despojos de los rendidos. Llevaban en medio y a trechos seis tambores en figura de hombres hechos de los pellejos de los curacas y capitanes chancas más distinguidos en la batalla; les habían arrancado la piel estando vivos para llenarlos de aire. Venían representando muy al vivo a sus dueños, con palillos atados a sus dedos, tañendo con ellos en la barriga momificada, todo como símbolo de vilipendio. En último lugar venía convertido en tambor el gran señor chanca de la provincia de Andahualas, muerto en la batalla. Al son de un enorme estruendo musical marchaban 4.000 soldados. Detrás iban muchos curacas y capitanes cautivos. Proseguían otros soldados y tras éstos otros seis tambores como los primeros. También conducían las efigies de sus divinidades.

A la postre de los cautivos, se veía el otro gran curaca Chanca (Lurin) que capturaron vivo en la batalla, lo traían desnudo y con las manos atadas atrás como los demás prisioneros, en una anda alta de maderos muy mal preparados, para que ignominiosamente fuera visto por las multitudes. Iban alrededor de aquella anda seis tambores confeccionados con las pieles de parientes suyos, con los que le iban haciendo son. Allí caminaba una tropa de pregoneros que incesantemente vociferaban que, de aquella manera, se intimidaba a los capaccuracas o apucuracas (reyes) que se obstinaban contra la etnia Inca; otros gritaban dando a conocer las acciones negativas cometidas por los chancas. Las trompetas y tambores con su desmedido y tremebundo estruendo causaban horror y espanto. Seguían a esta procesión 3.000 orejones opulentamente vestidos, adornados con diversidad de plumajes; otros entonaban 
el haylli o canto de la victoria, sucesos de la batalla, ánimo y valor del rey vencedor. Tras se desplazaban 500 doncellas hijas de señores principales, muy bien vestidas con guirnaldas de flores en las cabezas, ramos en las manos y cascabeles en los tobillos, vocalizando canciones y bailando a compás de las proezas del inca. A continuación aparecían muchos señores principales delante de las andas del inca quitando o simulando retirar las piedras y pajas del camino, y otros echando flores. Después aparecía el inca con gran majestad, imponencia y pompa en sus andas de madera fina y llana, forrada con láminas de oro; el asiento y peana donde posaba y ponía los pies, si totalmente de oro puro, muy labrado de diversas figuras. A los lados dos señores muy principales, de la familia real, que se iban mudando con dos quitasoles de plumas, muy bien obrados y muy elegantes traídos del Antisuyo cual tributo al inca. Guarnecían los tirasoles y los palos, unas planchuelas de oro de 24 quilates y esmeraldas. Servían estos tirasoles de palio, y le llamaban achigua. Empuñaba el inca en la mano derecha una estólica de oro; en la siniestra una vara de las que decían recibió del Sol. En la cabeza una borla mascapaicha de lana colorada muy fina que le ceñía la frente y pendía de una guirnalda de oro lindamente labrada. Los encargados de portar las andas eran 200 señores, mudándose a trechos de ocho en ocho. A éstos seguían algunos de la casta real y algunas pallas muy adornadas, traían en andas. Como remate venían 30 seńores de la casa del inca y de su Consejo, también en andas. Los quipucamayos conservaron en sus memoriales de que fueron tantos los runas que se hallaron en esta festividad de triunfo, que cubrían todos los altos y llanos de la redonda de la llacta del Cusco, que a grandes voces clamaban la valentía del vencedor y vituperaban la veleidad de las derrotadas chancas. Con el íntegro de este acompañamiento entró el inca a la ciudad del Cusco, dio vuelta a toda ella. Llegó a la plaza del Coricancha, mandó abrir los pechos para sacar los corazones de los cautivos, con la finalidad de quemarlos y esparcir las cenizas por los aires. Sin pérdida de tiempo penetró al templo; y postrado en el suelo dijo en voz alta una oración al Wiracuchan. Acabado dicho acto, calcinaron los sacrificios fuera del templo, donde siempre tuvieron un altar dedicado para esto, que sirvió esta vez para 10 días continuos (Montesinos 1642: 95-98).

En el Cusco fueron retenidos muchísimos chancas en calidad de arrestados, entre ellos el gran caudillo Anco Ayllu o Anco Huallo (Sarmiento 1572: 242).
Por lo menos 6.000 chancas, con sus mujeres e hijos, fueron retenidos en el Cusco para asimilarlos al ejército imperial con el fin de proseguir las expedicones conquistadoras por el norte (Ribera de Chávez 1586, I: 203). Una hermana de Anco Huallo fue tomada como esposa secundaria por Capac Yupanqui, para, mediante este enlace sellar una forzada paz y entendimiento (Cabello Balboa 1586: 314-316).

Una vez triunfantes los incas, les hubiera sido muy fácil castigar a los de Jaquijaguana por el apoyo dado a los chancas, pero no fue así. Pachacutec les perdonó, les obligó a reestablecer su antiguo señorío y luego a aceptar las disposiciones de los vencedores, pues - para ganarlos a su causa - les dio el rango de incas de privilegio, con orejeras. De ahí que les constrińeron a trasquilarse la cabeza entre ellos mismos, a imitación de los incas, que siempre llevaban el pelo corto (Betanzos 1551: 1 Pte. Cap X: 44).

Debilitados los chancas política y militarmente, hay que suponer que los incas los perseguirían para doblegarlos en su propio territorio. Llegadas las tropas a la provincia de Andahuaylas, envió a los chancas el consabido requerimiento para someterlos y callarlos de modo definitivo. Los curacas realizaron una junta, donde surgieron pareceres diversos. Unos opinaron sobre lo indiscutible de su derrota, lo que les apremiaba para su anexión en el Imperio. Otros reclamaron lo contrario, porfiados en no reconocer seńorío ajeno, impropio de tan valerosos guerreros, más bien enunciaban nuevos proyectos para reiniciar sus conquistas y no hacerse súbditos del Inca, pues aun les quedaba valor para resistir antes de aceptar tanta vileza. Varios días pasaron en estos debates, hasta que al final decidieron, por consejos de sus oráculos, seguir resistiendo. Lo cual sabido por el inca acordó ingresar a la provincia de Antahuaylla antes de que restauraran su osadía, confiados en sus victorias antiguas. La presencia del inca los amedrentó, resuelto como estaba a no seguir soportando tanta pertinacia y rebeldía. Los chancas al ver el numeroso ejército imperial, entre los cuales venían cientos de quechuas y otras naciones enemistadas con los chancas, disminuyeron su soberbia y decidieron aceptar el yugo de los incas, más por temor a las armas y evitar la venganza de sus enemigos. Pero el descontento y rencor no lo perdieron tan fácil ni brevemente (cf. Garcilaso 1609: 135). De allí prosiguió «a la otra provincia que llaman Uramarca», un remanente Chanca, pequeño en territorio pero poblado de gente brava y guerreros consumados que se resistía 
con gallardía, sin mostrar blandura ni atractivo por los incas. Según Garcilaso, al fin, con mucho disgusto y pesar los de Uramarca se supeditaron. De allí los guerreros del inca prosiguieron a "la provincia y nación llamada Hancohuallu y Uillca», es decir, Lurinchanca; pero ese Vilcas, a que hace alusión Garcilado de la Vega es, evidente, una inventiva de dicho cronista, por cuanto Vilcas era de filiación Tanquigua, que los incas iban a conquistar muy pronto (1609: 135-136).

En esta segunda expedición, Pachacutec persiguió pues a los chancas hasta sujetarlos por completo. Mató a todos los líderes y señores de la nobleza chanca que le pareció que podían tratar de resurgir; todo lo hacía para apuntalar su poderío. De nuevo puso curacas y señores de su mano, hijos de los que fueron victimados en las batallas, de los primeros que prendió y degolló en los encuentros iniciales. Acabado esto pasó a la conquista de Lucanas y Soras (Murúa 1616: 46).

Claro que la derrota chanca precipitó el estrechamiento de su territorio, ya que el permitido por los incas fue menor del que habían logrado echando a los quichuas.

Con su descalabro terminó su poderío bélico y político, por cuanto fue subyugado al Estado inca, pero no acabó su articulación étnica, sus ayllus y sayas continuaron en la provincia de Andahuaylas. Hasta le sacaron cientos de unidades domésticas para enviarlos como mitmas a Ancara para constituir una nueva provincia (Huancahuanca, Jatunhuayllay, Uchuhuayllay, Congalla y Julcamarca). Ulteriormente, conforme avanzaban las conquistas cusqueñas, prosiguieron las deportaciones chancas: en primer lugar a Zurite, en las proximidades del Cusco. Otro grupo a Pampaconga de las punas de Huarocondo. A otros los afincaron en San Jerónimo de Chacabamba, aledaño a Guamampalpas en el occidente del Cusco. Otro grupo a Parisha (Huanta). Un cuarto grupo fue trasladado a Copacabana para el servicio religioso del Sol y Luna. Pero la cantidad de chancas verdaderamente cuantiosa fue la obligada a caminar rumbo al sureste del señorío Ancara, en tanta cantidad que allí constituyeron un señorío autónomo. Finalmente se ha detectado otro grupo, si bien pequeño, en Macají en la sierra del Chimborazo, al sur de Quito (Julián Santillana 1012: 84).

El gobierno inca mandó levantar aposentos y almacenes. En Andahuaylas mismo dispuso la erección de un tambo que sería el intermedio entre Curamba y Uramarca. El tambo de Andahuaylas debía estar atendido por mitayos procedentes de "Andahuaylas, Oponguache, Chuquicocha, Vilar Puraychita, que son pueblos» (Vaca de Castro 1543: 144). Ordenanza que fue cumplida por los españoles.

Los mismos incas decretaron la reconstrucción, en la colina de Sóndor (Suntur) un complejo edificio de siete recintos, más 10 en Pucacorral, más cuatro callancas en Bandorcancha y un intihuatana en Muyumuyu, no solamente asociados a la red vial del capacñam, sino también a sitios ricos en metales preciosos: minas de oro en las inmediaciones del lago Pachucha y Andahuaylas, cuyas fundiciones debieron estar en el cerro de Huayhuaca. La zona en referencia también esta rodeada de bancos de arcilla, piedra y arena. Sóndor es uno de los principales monumentos epónimos del Horizonte Inca ubicado en la ruta que enlazaba al Cusco con Vilcashuaman. Sóndor fue realmente un lugar fortificado para observar el valle de Cotahuacho. Está orientado de oeste a este. De allí acondicionaron un camino a Curamba. Abrieron canales para traer agua (Pérez et all 303). En el mismo pueblo de Andahuaylas habilitaron un tambo a cargo de los chancas del dicho lugar y pueblos de Oponguanche, Chuquicocha, Villarpuraychita (Vaca de Castro 1543: 444).

De haber ganado ellos en la guerra e instaurado su hegemonía imperial en los Andes, la marcha de la historia habría sido bastante igual, por la sencilla razón de que en la sierra las estructuras sociales y económicas eran similares. Solamente en los reinos y señoríos costeños, de Nasca a Huancavilca, variaban sus modos de producción.

El vigoroso ejército inca, entre los cuales iba un escuadrón de de 6,000 chancas, fueron quienes conquistaron Soras y Lucanas. Iba comandado por los generales Inca Yupanqui y Guayna Yupanqui, hijos secundarios de Pachacutec, llevaban como consejero militar a otro hermano de ellos, llamado Auqui Yupanqui (Cabello 1586: 314).

En lo referente a los soras ya se anotó que Huayna Capac al hacer una inspección ocular para constatar la condición en que se encontraban las momias y estatuas de los sapaincas que gobernaron al país, descubrió que la de Pachacutec, su abuelo, necesitaba más servicio, Por eso mandó que los soras, lucanas y chancas de Andahuaylas fueran los yanaconas para el asistimiento de ese bulto disecado, por haber sido las primeras provincias que este gran señor conquistó y dominó en su vida (Betanzos 1551, I: XLI: 183). 
En seguida de haber descansado en aquellos soldados algún tiempo, la alta jerarquía inca planificó otra expedición por la misma ruta hacia el Chinchaysuyo. Pachacutec Inca Yupanqui dispuso que la capitanearan sus dos hermanos secundarios («bastardos»): Guayna Yupanqui y Capac Yupanqui, éste último en calidad de general. Por igual Apu Ynca Yupanqui, hijo de Inca Yupanqui. Como consejero en asuntos de guerra fue Apoc Ququiyupanqui, aunque secundario asimismo, el mayor del grupo. Todos con muchísimo armamento y un aparatoso ejército reforzado con renovados escuadrones que debían incorporarse en la ruta conforme se desplazaban al norte (Cabello 1586: 314-315).

Pero ocurrió algo muy característico en el espacio andino, dispuso que en este ejército fuera Anco Huallo, el lurinchanca que había quedado preso en el Cusco después de la derrota de sus guerreros en Cusco e Ichupampa. Por entonces Capac Yupanqui, para reforzar los lazos de dominación con tácticas de reconciliación y tranquilidad, había aceptado y tomado como esposa a una mujer lurinchanca, hermana de Anco Huallo. Este, por entonces, siempre andaba acongojado, imaginando como liberarse; lo hacía con tanto disimulo y arte que los cuscos llegaron a imaginar que ya lo tenían ganado como hermano ceremonial, por lo que se fiaban de él. El corolario fue que Pachacutec determinó nombrarlo capitán de los 6.000 chancas detenidos en el Cusco, para que fueran incluidos en el ejército expedicionario. No era nada insólita tal figura por ser costumbre inveterada en los Andes tal hecho, y porque cada nación participante en las conquistas llevaba como capitán a un jefe de su etnia, por considerar que ellos sabían mandar mejor a su gente por conocer más a fondo sus costumbres. Anco Huallo ante tal oferta, se avino dos veces y ofreció sus servicios por considerar que llegaba el momento de efectivizar su deseo. No ocultó su alegría ante el encargo y nombramiento que le otorgaba Pachacutec; prometió llevar a cabo grandes hazañas como hombre conocedor de las naciones chinchaysuyanas que iban a conquistar. El mismo sapainca repartió armas para emplearlas en la guerra: de oro para los generales, y de otros metales para los de rango menor. Les exhortó la valentía y anunció los premios que recibirían al retorno. A Capac Yupanqui le ordenó avanzar solamente hasta el río Yanamayo, frontera septentrional de la nación AtunGuayllas, donde debía poner los mojones imperiales y dejar instalado en los caminos el sistema de chasquis o postas para ser avisado día a día de las ocurrencias; después de dejar buenas guarniciones militares de mitmas debía regresar al Cusco sin incumplir esta disposición (Sarmiento 1572: 242-243).

Como se advierte, entre sus efectivos militares conducían a los animosos y orgullosos 6.000 chancas, capitaneados por Anco Huallo, todavía satisfechos por la campaña anterior en Parcos. Caminaban bajo la éjida de su divinidad tutelar encarnada en una efigie. En esta expedición reestructuraron y dejaron bien planificada la llacta de Vilcashuaman, acabaron la erección del suntuoso templo al dios Sol, dos acllahuasis, un tambo, callancas, un ushno, aposentos reales, etc. Como los de la etnia Quinua (Guamanga) se opusieron y armaron para desacatar a los cuscos, se parapetaron en una fortaleza natural aparentemente inexpugnable que, en la defensa de unos y ataque de otros, costó demasiada sangre, aunque venció el coraje y porfía de los incas; escarmentó u allanó la tierra de los quinuas (Cabello 1586: 314-315).

Reemprendieron el avance rumbo al norte, en cuya marcha los éxitos se sucedían unos tras otros. Cuando llegaron a la fortaleza de Orcucollac, en los alrededores de la provincia de Parco o Parcos (Parisha-Lauricocha), realmente cerca de este lugar (Huanta), los naturales ya estaban en pie de defensa, dentro de su fortaleza listos para la resistencia, los cuscos arremetieron dos veces, sin suerte. El tercer acometimiento tocó a los chancas, quienes aprovecharon la circunstancia para demostrar que seguían siendo más intrépidos que los cuscos. Determinaron capturar el fortín, o de lo contrario morir. Con tal pensamiento dirigieron su intención contra las cercas para atacarlas hasta perecer de ser posible. Como los parcos sitiados de percataron de las intenciones de los chancas, aparte de estar cansados de la ya larga resistencia, se sintieron desfallecidos. Fue entonces el momento, en plena mitad del combate, que las orgullosas chancas se arrojaron dentro de los muros con tanto denuedo que hicieron una mortal carnicería cortando las gargantas de los acorralados parcos. Cuando los orejones de Anan y Urincusco y sus tropas entraron ya no encontraron opositores a quienes degollar. Los parcos fueron vencidos en una colisión violenta, en la que destacaron los chancas capitaneados por Anco Huallo. Lo hicieron tan bien que quedaron dignificados, aventajando a los demás guerreros de la expedición expansiva, incluso al batallón de orejones incas. Tal hecho generó un profundo sentimiento de malestar y desilusión entre 
éstos, que sus capitanes apenas lo podían disimular. Pronto enviaron mensajeros a Pachacutec Inca Yupanqui, que permanecía en el Cusco. El supremo gobernante, ofuscado y entristecido por lo ocurrido, no por la conducta loable exteriorizada por los chancas, sino por el descrédito de los Anan y Urin Cuscos, no le quedó más opción que disimular su indignación y angustia ante el desagrado causado por la deshonra experimentada por los guerreros de su nación, en contraste al mérito de los chancas con su indiscutible triunfo. Sospechó que iba a ser el reinicio de la soberbia y rearme psicológico-militar con graves consecuencias. Astutamente meditó mucho para dictar actos de venganza, castigo y exterminio para acabar con la zozobra de que los chancas recobrasen su poder de mando, dejando a los cuscos en condición de infelices. Después de tanto cavilar trazó un plan estratégico de futuro exterminio de la integridad de Chancas comandados por Anco Huallo. No quizo aceptar que los chancas aventajaran en esfuerzo, brío y gloria a los cuscos, con el riesgo de ser más honrados que los demás (Cabello 1586: 313-324).

$\mathrm{Al}$ norte, al Chinchaysuyo, a lugares rodeados por atuncuracazgos o naciones que defendían su libertad, Pachacutec envió un mensajero al general Capac Yupanqui, con la orden contundente de desaparecer a los chancas que caminaban tan lozanos y orgullosos de su comportamiento en la fortaleza de Urcucolla en Parcos. El corolario fue autorizar al capitán general Capac Yupanqui para que éste ordenara la matanza generalde los chancas que operaban en el ejército imperial, para lo cual debía aprovechar determinadas batallas o toma de alguna fortaleza dificultosa, colocándolos en la delantera y en lo más peligroso, para que muriesen o por lo menos quedasen apocados, o cualquier otra ocasión para liquidarlos. Debía colocarlos en forma tal que en las combates fueran los primeros en ser muertos por los guerreros de las etnias atacadas que defendían sus libertades; y de no funcionar esta maniobra, los mismo orejones y demás cuscos los atacaran briosamente, de tal manera que no quedase ni uno que difundiera esa noticia por ninguna parte (Cabello 1586: 314-315). De incumplir esta orden, la sentencia recaería sobre Capac Yupanqui. Cuando llegó el mensajero a media noche para evitar sospechas, relató la disposición de Pachacutec en el interior de su tienda o carpa de dormir, lo hizo delante de la hermana del capitán Chanca, que era una de las esposas secundarias de Capac Yupanqui, en cuya cama yacía, por lo que pudo escuchar lo que se tramaba. Con la preocupación de salvarlos, salió como mejor pudo del aposento o carpa de campaña de Capac Yupanqui para encaminarse en pos de su hermano, quien se sorprendió ante tan ingrata novedad con las más encarecidas y sentimentales palabras para salvarse del daño inminente que les venía. Ella dio aviso a su hermano en forma sigilosa, con lo que velozmente dejó de ser un absoluto secreto militar. La mencionada hermana de Anco Huallo, con gran esmero velaba por la salud y vida de su hermano y de los de su nación, supo aprovechar las facilidades que gozaba en el acceso y movimiento en el campamento de los cuscos. Enterados los jefes chancas, para escapar de la muerte que les esperaba, desesperados decidieron huir a toda prisa una noche, escapando del campamento de carpas levantado en el tambo de Huaraz. Anco Huallo, quien invariablemente tenía en mente el ansia de la liberación de sus connacionales, frente a tan angustiante noticia sintió más prisa para poner en acción lo que planeaba; con prudencia y animosidad soportó la ira. Con el pretexto de ejercicios de combate, llamó a sus capitanes, subalternos y más notables de su tercio. Se valió de un momento en que ningún cusco ni forastero le oyera ni mirara, para con frases elocuentes y agraciadas, comunicarles lo que se tramaba contra la vida de ellos. Sus alocuciones exaltaron la furia y crueldad de Pachacutec y los incitó a que lo siguiesen en una fuga sigilosa y heroica. La aceptación fue unánime, todo sin bullicio ni alboroto para salir del servicio de un sapainca tan ingrato. Prosiguió la marcha hacia el norte, hasta arribar al tambo de Guaraz (Huaraz), al septentrión de Huánuco y sur de Guayllas. De modo que estando el ejército en pleno descanso en una noche, caminaron por en medio del enorme campamento compuesto por innumerables guerreros pertenecientes a todas las naciones hasta ese momento conquistadas por los incas, sin que el servicio de guardias se pudiera dar cuenta. Aquí, a la media noche, sin el menor rumor y bullicio, con rapidez los chancas - hombres, mujeres y niños - se juntaron y apiñaron, formando un solo cuerpo salieron del gran campamento inca sin que Capac Yupanqui pudiera escuchar nada. Cuando algunos pelotones imperiales se dieron cuenta del movimiento creyeron que sus capitanes y generales preparaban algo en silencio; mientras que otros de etnias no cusqueńas utilizaron la calma reinante para ponerse de píe y seguir a la totalidad de Chancas que escapaban comandados por Anco Huallo, colmados de nostalgia por abandonar voluntariamente su 
patria chanca (Andahuaylas); realmente les siguieron otros escuadrones pertenecientes a diversas naciones, lo que indica que cientos de soldados servían contra su voluntad. Ya en la madrugada recién pudieron percibir la sagacidad y astucia con que salieron los chancas; corrieron a detenerlos, pero fueron muertos por los que fugaban. Así llegaron a la "provincia» de Atunguayllas (hoy Huaylas). Al amanecer, los cuscos quedaron desengañados, se dieron cuenta del mal resultado de sus maniobras, pues los chancas ya estaban a distancia muy avanzada, no les pudieron dar alcance. Al pasar por Guayllas, precisamente, sus habitantes se imaginaron que arribaban los incas, por lo que salieron a recepcionarlos pacíficamente.

Pero como pusieron al descubierto lo que sucedía, los chancas hirieron y mataron a cuantos pudieron. Todavía los chancas fueron informados, ilusoriamente, que el sapainca y su capitán general los perdonarían y readmitirían apaciguadamente. Esperaron algunos días, y al no sentirse seguros, tomaron todo los alimentos y ropajes que les fue posible de la citada provincia de Guayllas para lograr abastecimientos, gracias a lo cual la muchedumbre prosiguió su escapatoria por caminos abruptos y montuosos. Al pisar el ámbito de Conchucos, cansados por la celeridad de la evasión y peso de la estatua del dios Chanca, la abandonaron. Doblaron al este, atravesaron la cordillera interpuesta entre Huaylas y Collay (sur de Chachapoyas); se internaron hasta llegar a la tierra denominada Hanamayllo y Ruparrupa (Motilón, Saposoa, Lamas), a donde los incas, aunque los buscasen, no los iban a poder descubrir. Se sabe que, con increíble enojo, él mismo capitán Inca con sus guardas y centinelas los siguió con mucha fogosidad con la intención de pasarlos a cuchillo. En efecto, Capac Yupanqui los persiguió, sin nunca más alcanzarlos; su furia y diligencia fue impracticable porque la vehemencia era mayor en los que huían. Cuando pudo darles vista estaban en partes por donde ninguna vía podía dar acceso a ellos. En Huaraz, por consiguiente, se escabulleron algunos miles de chancas. Se asegura que se estacionaron entre los ríos Pacay y Cocama o Huallaga, cerca del Motilón y Saposoa. Capac Yupanqui, por su lado, tomó otros rumbos de expansión y conquista para congraciarse con su hermano el sapainca. Mientras tanto otros miles de chancas continuaron en Andahuaylas, considerada su "patria»; controlados por mitmas de guarnición siguieron conservando sus formas de vida, prologando sus usos y costumbres. (Sarmiento 1572: 242-243
/ Cabello 1586: 314-316 / Murúa 1616, I: cap. 21 / Calancha 1638: 473).

En su fuga a la montaña iban sujetando todas las naciones que topaban hasta encontrar en aquella región tierras fértiles, ricas y a propósito, donde se establecieron. Decían que se detuvieron en las riberas de una gran laguna, con grandes poblaciones en su circuito, muy extendidas. La corte y cabecera resultó ser en Casas Blancas, muy poblada. Se cuenta que siguieron conquistando y fundaron un señorío. Se convirtieron en leyenda y mito. Contaban que como descendientes de un león feroz, al que adoraban por divinidad, lo adoptaron como señal heráldica, en sus fiestas se ponían sus pieles (Vázquez de E. 1630: 510-1480).

Capac Yupanqui, ya sin efectivos chancas, pero de todas maneras bien apertrechadas de guerreros y armas, prosiguió al norte hasta Caxamaca, Después de sus victorias retornó al Cusco para celebrar el triunfo. Pero Pahacutec no los premió ni remuneró con nada por sus trabajos, mejor dicho no hubo redistribución de bienes ni de prisioneros. Más bien Pachacutec exteriorizo su descontento de que su hijo y heredero no hubiese disfrutado de la honra, y de que Capac Yupanqui se hubiese excedido en las conquistas territoriales; Si bien esto era el pretexto, la auténtica causa de su desaprobación se apuntalaba por haber descuidado en dirigir la mortandad de los chancas. El corolario fue la pena de muerte para sus hermanos Capac Yupanqui y Guayna Yupanqui. Al sapainca no le importaron las críticas de sus allegados (Cabello 1586: 317-318).

El colmo de la audacia de los desconsolados guerreros incas fue volver al Cusco cargados de prisioneros y despojos. Pachacutec Inca Yupanqui salió al camino para entrar todos a la ciudad triunfando, como si la victoria hubiese sido el resultado de la fuerza y táctica militar de los cuscos (ibid: 313-324).

El Estado imperial con su capital en el Cusco, inventó un suceso excepcional para castigar la fuga chanca de Huaraz, venganza que debían experimentarla los sobrevivientes de Andahuaylas. Para eso tergiversaron y engañaron, valiéndose de la magia y religión, intransigentes para no desdibujar la imagen del Estado Inca. Al respecto hay un episodio digno de ser anotado. Se refiere que un militar inca llamado Sinchi Roca que persiguió a los agoreros, dejando con vida solo a los adivinos de la guerra y secretos militares. Consultó con ellos sobre el "rey chanca» de Andahuaylas, de quien, pese a estar ya vencido, se tenía 
serias sospechas de su lealtad. Los aurúspices, enseguida de sus actos ceremoniales, contestaron que estaban rebelados, por lo que se les debía atacar y obligarles a la sujeción, pues los pronósticos anunciaban cruentas batallas pero en la que se ganaría.

Envió espías, los cuales informaron que el descontento de los chancas de Andahuaylas no estaba originado por el poderío de los incas, sino porque sus oráculos les afirmaban que los sapaincas no eran legítimos seńores o reyes, por lo que no se les debía obediencia. Por eso el Inca convocó gente formando un grueso ejército bien proveído de armas y víveres. Se encaminó con un general de satisfacción en dirección a Andahuaylas, hasta parar en un lugar donde le llegase un chasqui con nuevas órdenes. Envió mensajeros al nuevo curaca Chanca, manifestándole su preocupación por haber quebrantado la lealtad manifestada por sus antecesores por confiar en las respuestas de sus oráculos. Todavía les remarcó reconocer como dioses al Sol y Luna, de quienes descendía el sapainca, verdaderos seńores de la Tierra. Le advirtió no perturbar la paz con derramamiento de sangre; de deponer sus decisiones les perdonarían lo acontecido. Pero la contestación del gran curaca Chanca fue que ya tenía su ejército listo, en lo cual había gastado mucho para resistir al que le quería quitar la libertad. Ante tan fuerte respuesta mandó el sapainca un desplazamiento lento, poco a poco meditaba acudir él mismo con suficientes refuerzos. Así se llevó a cabo. Los batallones se enfrentaros en los altos de Andahuaylas, una legua antes de llegar al pueblo. Los chancas eran todavía muchos, tantos que causaron temor a los incas. Pero el sapainca, volvió a revivir la alucinación anterior, en la que, según él, se le apareció en sueños el Sol que le mandaba dar batalla con la seguridad de la victoria, garantizándole con la entrega de tres varas doradas y cinco piedras cristalinas con una honda mágica. Alentados los soldados, tocaron sus trompetas y tambores con estruendo tal que parecía temblar la tierra. El sapainca se puso sobre las trincheras y disparó las tres varas; colocada una piedra cristalina en la honda la tiró con todo brío a sus enemigos. Los soldados hicieron lo mismo. Se trabó una sangrienta batalla que duró muchas horas sin conocer triunfo por ninguna de las partes. El número de cadáveres estorbaba el movimiento de los vivos.

Entonces el inca usó otro ardid notable; al entrar la noche trató de hacer una retirada bien concertada en la oscuridad. Por un lado dejó bastantes soldados escondidos. A los chancas les pareció que escapaban por lo que fueron en seguimiento desordenado. El inca volvió sobre ellos hallándolos confundidos; masacró a muchos de la vanguardia; simultáneamente salieron los emboscados para cogerlos por las espaldas. Dejaron sin vida y apresaron a un sinnúmero de chancas. Fue preso un capitán y otros muertos, mientras el rostro del Inca resplandecía de felicidad (Montesinos 1642: 93-95). Con maquinaciones de este tipo, premeditaban demoler la moral y prestigio chanca, opacándolos en lo posible, plan que los incas lograron en grandísima parte, con el plan de «sojuzgarlos para siempre». Es justamente el factor para que, hasta hoy, los descendientes de los chancas, manifiesten su discrepancia contra los incas del Cusco.

Tal fue la versión oficial sobre exaltada por los jefes incas, bien que los allegados a la política imperial sabían que éstos estaban alegres de que los guerreros chancas hubiesen fugado y desaparecido, para atenuar la preocupación que experimentaban ante el congénito carácter valeroso de los perdedores. Pachacutec inquirió los pormenores de esa fuga, y de la manera en que quedaba la provincia de Andahuaylas y las otras hasta Huaraz. Al enterarse que todo estaba controlado, entró en calma, dispuso que un hermano suyo y dos más del consejo fueran bien guarnecidos a visitar los ayllus chancas disimulando su proceder con blandura y mansedumbre, con el objetivo de aquietar los ánimos de los chancas conmovidos por la fuga de Hanco Huallu. Efectivamente empadronaron las sayas $\mathrm{y}$ ayllus, incluso inspeccionaron las antiguas fortalezas chancas de Challcumarca y Uramarca, en las cuales estuvo Hanco Huallu los días postreros de su reinado (Garcilaso 1609: 186-187).

Pasado y sosegado lo pertinente a la fuga de los chancas y acabada la visita se volvieron al Cusco hasta olvidarse de la citada huida. Para seguir repoblando la destruida provincia de Andahuaylas trasladaron a multitudes de mitmas, en esta oportunidad en cantidad de 10.000 unidades domésticas con el designio de reemplazar a los muertos en Yahuarpampa, deportados y escapados. Como jefes o curacas procuraron designar a incas de privilegio, para llenar los vacíos dejados por los fallecidos y exilados señores chancas de su ex reino (ibid: 187). En el Cusco, concomitantemente, los incas desataban un intenso sistema de reorganización politica, económica y social.

La provisión firmada por La Gasca aclara que los incas les pusieron mitmas de control compuestos por orejones del Cusco en cuatro lugares, en uno de los 
cuales residía un tucuyrico o espía-inspector; quichuas en tres sitios, aymaras, hasta se habla de mitmas tan lejanos como es de Chachapoyas. En lo pertinente a los dos pueblos denominados Yungas, uno en Anan Chanca y otro en Lurin Chanca, se trata de sus enclaves de cocales y otros productos de clima cálido en el valle de Mayocmarca.

En efecto, apenas se han encontrado documentos indicadores de la presencia de un grupo de mitmas Chachapuyas que fueron enviados para cumplir trabajos concretos en el tambo de Uramarca y en Huancarama. También hubo mitmas traídos de Guayacundo y Guayllabamba (Vaca de Castro 1543: 444), por igual de Tanquigua. Los chachapoyas en las punas de Huancarama fueron distinguibles hasta fines del siglo XIX.

Aparte de cientos de chancas que fueron desterrados a Parisha (Parija-Huanta), Ancara, Quispicanchi, Copacabana, etcétera, y enrolados para incrementar las tropas del imperio. Precisamente un papel de 1705 manifiesta "los indios chancas del repartimiento de Guanta, provincia deste nombre» (BNL. B14775).

Los Chancas mitmas residentes en Quispicanchi fueron ubicados en el paraje que desde entonces recibió el nombre de Antahuailla. Intervenían en la festividad del Situa (agosto), éstos recibían de ciertos corredores unas antorchas para pasarlas a los mitmas de Huayrapacha (Molina 1575: 38). Este Antahuaylas al que se refiere Molina es al que los espańoles primero llamaron Andahuaylas la Pequeña o Chica y después Andahuaylillas al sur del Cusco.

Otros cientos de chancas, a su vez, fueron deportados por diversos lugares. Se cita un repartimiento denominado Ancoayllo y Ayanque en Urcosuyo de Cavana y Cavanilla [Lampa]; puede que se trate de algún grupo chanca desterrado por allí (AGL / Miranda 1581: 130. P I / López de C. 1630, II: 87).

En Nuñoa - Orcosuyo del Collao: Atuncolla- se menciona en la visita toledana de 1573 la existencia del «repartimiento de Hancoayllo». Al parecer de 80 tributarios o unidades domésticas lurinchancas desterradas como mitmas (Miranda 1583a: 153).

Por documentos fidedignos conocemos de la existencia de un "pueblo» llamado Chanca que puede ser un lugar de mitmas. No sabemos el sitio preciso, pero estuvo, en algún lugar de la jurisdicción del Cusco. En la visita general encontraron 47 tributarios, ocho viejos, 54 muchachos y 103 mujeres. Total: 212 personas. Pertenecían a la encomienda de Gómez de
Tordoya, Pedro Vásquez de Vargas, doña Francisca de Robles y Juan Fernández Valenzuela que tenía una parte de estos chancas y otros de Micha, Chuchupilca y Uchubamba. Las 47 tributarias chancas pagaban su tributo con 235 pesos de plata ensayada y marcada: los 164 y medio en plata y lo restante en 23 fanegas de maíz y 18 fanegas de trigo a peso y medio cada cual, y 62 aves de Castila a tomín cada una. No tenían curaca, pero si pensiones de 49 pesos para el sacerdote doctrinero, 29 para el justicia y protector, 14 pesos para la comunidad y 86 para los encomenderos (Miranda 1583b: 191).

Aparte, decidieron enviar mitmas chancas hacia más lugares: un grupo a la etnia Tanquigua. Se mencionan siete asentamientos de mitmas chancas en Ancara o Angaraes (Ribera de Chávez 1586, I: 203 /1965), a 250 kilómetros de Andahuaylas. Otro ayllu de Chancas a Zurite, cerca al Cusco; otros en las punas de Huarocondo, en el poblado de Pampaconga, este último a 150 de Andahuaylas. Más mitmas al occidente del Cusco, en San Jerónimo de Chancabamba, junto a Huamampalpa. Y otros mitmas chancas trasladados a Macaji en el Chimborazo, al norte de Tumebamba (Santillana 2002, II: 563).

Lustros después, durante el regreso de Huayna Capac, ulteriormente de la derrota definitiva de los Caranquis al norte de Quito, al ingresar a la provincia de los Chancas, para escarmentar, impuso más sanciones a los culpables de la presunta conspiración (Montesinos 1642: 124).

Finalmente, años más tarde, al caminar unos guerreros incas por la provincia de Andahuaylas, hábitat de la nación Chanca, éstos fueron llamados»traidores», sobrenombre que les duró hasta inicios del siglo xvir. Al decir chancaruna siempre añadían auca, que justo quiere decir alevoso, aunque también es tirano, fementido, guerrear y dar batalla: tantas cosas en una palabra sola (Garcilaso 1609: 182). Así desprestigiaban los incas a sus opositores, usando la historia mítica que tanto les agradaba fabricar a su favor. Es tangible, entre chancas e incas no hubo lazos de simpatía.

La sujeción de los incas les atajó para siempre sus buenas andanzas; de señores de vasallos pasaron a ser tributarios del soberano cusqueño. Fue el germen para que aumentara su inquina heredada de sus padres (Ibíd: 145).

Pero en la historia verdadera, los chancas fueron célebres como guerreros, agricultores y pastores. No obstante su derrota inflingida por los incas, alcanzaron 
a ser convertidos en mito y leyenda. Se inventó que conquistaron algunos señoríos vecinos; fraguaron relatos para hacer creer que ensancharon sus dominios, por lo que poco a poco fueron entrando a tierras más lejanas, como a las afamadas de Contisuyo y la misteriosa Tucaysuyo. A las que rindieron, prosiguiendo adelante para asolar a quienes resistían; que dominaron la provincia de Collasuyo y llegaron hasta los rústicos, belicosos e invencibles chiriguanos, a los que vencieron después de algunos choques agresivos, los hicieron sus vasallos dejando guarniciones y gobernadores al igual de lo realizado en la etnias anteriores. Enseguida dieron vuelta con la ilusión de conquistar el Cusco (Montesinos 1642: 25).

(Bastante se ha escrito — noveladamente- con el propósito de probar la presunta suposición de haber existido "la confederación Chanca» con diversidad de lenguas y etnias en un espacio que - se dice- pudo haberse extendido desde la provincia de Aimaraes —departamento de Apurimac- por el sur, hasta el lago Choclococha en el noroeste, de modo que habría incluido la cuenca del río Pampas en Ayacucho con prolongaciones hasta el valle de Chincha; aunque hay otros autores que lo dilatan por el norte hasta el área Huanca — sur del departamento de Junín—, con el agregado de que se confederó con una etnia imaginariamente llamada Pocra. Sin embargo, nada de esto ha sido dable demostrar con veracidad, incluso la existencia de la "nación Pocra» es fruto de de la ilusión del inca Garcilaso).

Cuando el pacificador don Pedro de La Gasca estaba en Jauja aguardando a la gente de Lima, Trujillo y Quito para marchar contra Gonzalo Pizarro, se informó que 23 arcabuceros del rebelde, comandados por Pedro de Bustinza habían arribado al pueblo y tambo de Andahuaylas, en el que capturaron al curaca Guasco, simpatizante de los realistas (Calvete 1567, IV: 404). Sin embargo, al cruzar 15 arcabuceros leales al rey capitaneados por Mercadillo y Lope Martín, al encontrar preso al curaca de los chancas, lo hizo soltar. Con todo, los ayllus chancas se encontraban contrariados por los daños recibidos el día de la batalla. Por ejemplo al llegar los espańoles gonzalistas sublevados a Guancaray, pueblo de la etnia Chanca, habían rancheado e incendiado casas, pirguas de maíz y otros bastimentos (El Palentino 1571, I: 219-220 / II: 32).
La Gasca envió soldados realistas a Andahuaylas para entretener y animar a los curacas de aquella provincia, para que no se doblegaran ante la nueva de aquella victoria de Gonzalo Pizarro; pues quien tenía por entonces el apoyo de los curacas tenía a los runas cargueros, chasquis o correos y abastecimientos. De caer en poder de Gonzalo Pizarro, el ejército del rey al pasar por esa comarca y provincia, sufriría gran trabajo y riesgo de padecer hambre (Calvete 1567, IV: 405).

Los chancas con su apucuraca Apo Uasco, unidos estos con efectivos allauca-huánucos presididos por Martín Guaman Malque de Ayala, derrotaron al rebelde Francisco Hernández Girón en la batalla de Gunca-Cocha, junto a Ora-Yaoma. Más tarde los huancas capitaneados por Apo Alanya Chuquillanqui, acabaron capturándolo en Xauxa (Guaman Poma 1615: 409 (411, 433 (435).

En el treceño de 1540 a 1553 su curaca mayor tenía, en efecto, el nombre de Guasco (Cieza 1553: 436). En la cédula de encomienda firmada por el virrey don Antonio de Mendoza, en 1552, se refiere «a vos don Diego G[u]asco, cacique, e a los demás principales e indios e mytimaes vuestros sujetos, que al presente soys e después de vos sucedieren y estuvieren en el repartimiento e pueblo de andahuaylas». Son frases que señalan que no se trata de mitmas de enclave, sino de adscritos que quedaron bajo el mando del capaccuraca Chanca (AGI. P-93).

Sirvieron muy bien al gobierno colonial. Particularmente cuando el licenciado don Pedro de La Gasca fue con el ejército real contra Gonzalo Pizarro; trabajaron y consumieron muchos bastimentos y cargadores (Vázquez de E. 1630: 510-1480).

Cuando fue creado el corregimiento de la provincia de Andahuaylas, en 1565, lo dividieron en seis repartimientos: Andahuaylas, Guancarama, Cayara, Ongoy, Oripa y Ocobamba (López de C. 1630, II: 93). En el corregimiento funcionaban cuatro tambos reales: Andahuaylas, Uranmarca, Pincos y Cochacajas (La Carrera 1610: 122r). Por entonces, el señorío Chanca de Andahuaylas estaba ya muy resquebrajado, por cuanto cada repartimiento entregado a un encomendero espańol, éste lo administraba económica y socialmente como cosa propia, transgrediendo las leyes por cierto. Las tierras que fueron el Estado Inca y de las divinidades fueron declaradas realengas, es decir propiedad del rey de España, aptas para cederlas a los hispanos interesados en instaurar haciendas, estancias y fincas. Se inició el colonialismo hispano. 
Los españoles le llamaron Andahuaylas la Grande, para diferenciarla de Andahuaylas la Pequeña, una reducción al sur del Cusco, ahora denominado Andahuailillas. Andahuaylas la Grande fue encomienda de Diego Maldonado el Rico. Le sucedió su mujer doña María Francisca de Guzman. En 1575 durante el virrey Toledo ya la disfrutaba el encomendero don Jerónimo de Figueroa. Fue empadronado por el visitador Juan de Palomares, fundador de las reducciones chancas. Se aclaró que por la «tasa vieja» rentaba 10.404 pesos ensayados. Ahora el citado virrey le quitó la mitad, es decir, 5.202 pesos. El mismo Toledo muy pronto puso la etnia Chanca en la Corona Real el 6 de septiembre de 1579 con los demás repartimientos de la misma provincia, con lo que el antiguo curaca principal recobró su prestigio, aunque supeditado al corregidor y al doctrinero. Los tributos los recaudaba la Caja Real Cusco, para enviarlos a Lima, y de aquí a España (Toledo 1575; 78 / Miranda 1583b: 115 / La Carrera 1610: 122r).r

Los chancas fueron empadronados o visitados en 1573, año en que fueron planificadas sus reducciones o pueblos. Los censadores encontraron 5.330 tributarios. Los 3.201 de la parcialidad de Ananchanca y los 2.109 de Lurinchanca. Más 2.428 viejos; 661 muchachos de 17 ańos abajo; 14.811 mujeres de toda edad. Total: 28.848 personas: 17.088 ananchancas y 11.752 lurinchancas. Cada saya o mitad tenía 10 curacas, mejor dicho, 20 señores (Miranda 1583b: 115). Como se advierte, todavía sumaban miles de habitantes.

En cuanto a Cayara mismo, el tercer repartimiento, quedan algunos datos más. Tenía 3,203 individuos, de los cuales 303 eran tributarios, reducidos en cuatro pueblos: San Pedro de Cayara, Santiago de Mollebamba, San Marcos de Uchubamba y San Juan de Recche. 2o Uripa con 1.961 habitantes, de los cuales 315 con la categoría de tributarios reducidos en el pueblo de Villa de San Pedro de Toro. $3^{\circ}$ Ongoy, con 1922 pobladores, 326 de ellos tributarios reducidos en dos pueblos: Nuestra Seńora de Ongoy y Santiago de Visibamba. Y $4^{\circ}$ Ocobamba, con 1.721 habitantes, 285 de ellos tributarios reducidos en el pueblo de igual nombre (Miranda 1582a: 169). Total de personas: 8.807 habitantes. Sumados a los anteriores ascendían a 42.077 pobladores repartidos en 10 ayllus y dos sayas. Hay que considerar que tales cifran aparecen en 1583, lo que anuncia que en la era del Tahuantinsuyo fácilmente sumarían 150.000 personas, que moraban en una extensión de 7.419 kilómetros cuadrados aproximadamente.

La tasa seńalada fue: 1) 5.310 pesos de oro quintado y marcado de 22 quilates y medio cada uno; en plata ensayada y marcada equivalía a 6.637 pesos y medio. 2) 1.325 piezas de ropa de awasca, por mitades de varón y mujer, valuada cada pieza en dos pesos de plata ensayada y marada: montan 5.650 pesos. 3) 300 llamas o "carneros de la tierra" de año y medio para arriba, a 2 pesos y medio de plata ensayada cada uno, totalizaba 750 pesos. 4) 100 pacos de dos ańos y medio para arriba, a peso y dos tomines de plata cada uno; rentaban 125 pesos. 5) 1.185 fanegas de maíz a un peso de plata la hanega; rendía 1.185 pesos. 6) 120 fanegas de trigo a un peso y dos tomines de plata la fanega, montan 400 pesos de dicha plata. 7) 400 fanegas de papas a cuatro tomines plata cada hanega, redituaba 200 pesos. En suma, toda la tasa anualmente se elevaba a 21.240 pesos de plata ensayada y marcada. La división matemática muestra que cada chanca tributario entregaba, en promedio, 4 pesos de plata ensayada y marcada (Miranda 1583b: 115).

Los egresos ascendían: 1) 4.400 pesos de palta ensayada y marcada: 4.000 en plata y 460 fanegas de maíz, 160 de trigo y 80 de papas para el salario de ocho clérigos doctrineros, a razón de 550 pesos cada uno. 2) 260 pesos de plata ensayada y marcada para la fabricación de la iglesia de la cabecera. 3) 500 pesos de plata para el hospital provincial. 4) 200 pesos de plata para la fábrica de las otras iglesias de la provincia. 5) 1.000 pesos de plata para el salario del justicia $y$ defensores de naturales. 6) 1.052 para salario de los curacas. Suma total: 7.212 pesos de plata ensayada y marcada. Sobraban 9.292 pesos y 4 tomines que los chancas pagaban en plata, 2.480 pesos y 4 tomines. Restaban 6.636 y 4 tomines ensayados que valían los 5.310 pesos de oro fino que entregaban los chancas, convertidos a plata ensayada a $25 \%$ de interés. De los 5.310 pesos que montaba la ropa, ganado y demás cosas pagados en especies, figuraban los 4.910 pesos. Lo sobrante en oro, plata y especies sumaba, reducido a plata ensayada, 14.028 pesos ensayados y marcados enviados a la Corona Real (Ibid: 115-116). Proseguían disfrutando de su enclave de coca en la Montaña.

En la visita toledana no le dieron el nombre de Chanca, sino el de «corregimiento y provincia de Andahuaylas», en el compendio del padrón no los registraron censados por sayas o mitades, sino en 
conjunto, arrojando la suma de 5.330 tributarios y 28.840 exonerados. Total 34.170 habitantes, concentrados en 13 pueblos: San Pedro de Andahuaylas la Grande, San Jerónimo de Casana, Nuestra Señora de Talavera de la Reina, San Juan Evangelista de Guancaray, Santiago de Guancaray, San Juan Bautista de Turpo, San Francisco de Chillana, San Sebastián de Cota, Santo Domingo de Ulcay, San Miguel de Charamba, Santiago de Guayana, Nuestra Señora de las Nieves de Onamarca y San Cristóbal de Pampachiri (Miranda 1582a: 168-169). Ulteriormente se formaron San Francisco de Churisana, Santiago de Ulcayba y San Miguel de Chacaracha, ubicados en torno de cuatro leguas desde el núcleo de su reducción. También San Felipe y Santiago de Pomacocha, estos dos en distancia de dos leguas (Arce de Quiroz: 1604: 42r - 42v, 48r. A,H. Cusco. Sección Andahuaylas).

En 1603 los pueblos de la provincia de Andahuaylas fueron numerados así: San Pedro de Andahuaylas, San Jerónimo, Nuestra Señora de Talavera, San Juan de Turpo, San Cristóbal de Pampachiri -»que es en la puna»-. Humamarca, Guayana, Vecaybacuy, Cola, Churicana y Cache (Arce de Quiroz 1603: 161r $-107 \mathrm{r}$ ).

En 1604 Andahuaylas seguía con su estatus de "pueblo Cabecera» de "toda» esa provincia, o sea, que dicha categoría no la perdió en el curso del virreinato (Ibid: 40r).

No obstante que los espańoles prefirieron, desde un comienzo, llamarle oficialmente provincia de Andahuaylas, lo cierto es que en la onomástica campesina prevaleció el gentilicio "Chancas de Andahuaylas». Esto ya es percibido desde tiempos antiguos, por ejemplo en la retasa del 17 de mayo de 1618, en que contaron 3.130 tributarios, de los cuales sacaban para la mita de Huancavelica 250 mitayos, aunque en dicho año fueron rebajados a 200 (AGI. L-39).

Un expediente de 1614 adjudica al corregimiento o provincia de Andahuaylas los siguientes pueblos, ya con la categoría de cabezas de doctrina: $1^{\circ}$ San Pedro de Andahuaylas la Grande. $2^{\circ}$ San Jerónimo. $3^{\circ}$ Talavera. $4^{\circ}$ Huancaray y sus anexos Turpo y Huancaray el Chico, separado éste último por el río mayor en distancia de dos leguas. $5^{\circ}$ Colay y su anexo Chulicana en un ámbito de dos leguas. $6^{\circ}$ Guayana o Huayana y sus anexos Ulcay, Guanacha y Curampa en un espacio de tres leguas. $7^{\circ}$ Pampachiri y sus anexos Omamarca y Pomacocha en un ámbito de tres leguas. $8^{\circ}$ Guancaroma y su anexo Cotarma en un espacio de cinco leguas. $9^{\circ}$ Oncoy con sus anexos Piscobamba, Omaca y Ocobamba, en una distancia de cinco leguas. $10^{\circ}$ Oripa y sus anexos Cayara, Cocharca, Lollepampa y Uchupampa en distancia de seis leguas. $11^{\circ} \mathrm{A}$ lo que hay que agregar su enclave de Mayocmarca, valle de cocales, ubicado al este del señorío de Quinua o Guamanga. Por entonces las doctrinas de Oncoy y Oripa estaban cargadas y obligadas a pagar a varios vecinos de San Juan de la Frontera de Huamanga, por lo que entraba a ellas el alcalde de la Hermandad de esta ciudad; de ahí que el obispo de esta diócesis opinó que lo anexaran a su jurisdicción (División del obispado del Cuzco. 1614. AGI. E-C 503).

En la primera mitad del XVII se enumeran los pueblos de Andahuaylas, San Jerónimo, Talavera y Mayomarca; Guancarac y Tierpo (sic); Colay y Chulicana; Guayana, Vilcay, Huanichacarampa, Pampachiri, Omamarca y Pomacocha, Guancarama y Cotarma; Oncoy, Piscobamba, Omaca, Yocobamba; Oripa, Cayara, Cocharca, Mollepampa, Yuchupampa (División de los obispados 1616: 146. P 11). En las fuentes hay carencia de homogeneidad en el listado de los pueblos y doctrinas. Puede ser el resultado de reacomodos y reformas permanentes, a solicitud de los propios interesados campesinos, o quién sabe por conveniencia de los obispados y vicarías.

Otra fuente señala los seis repartimientos de Guancarama, Andahuaylas, Cayara, Ongoy, Oripa y Ocobamba (Vázquez de E. 1630: 654). Documentos de $1628,1720,1820,1826$ y 1830 suministran los siguientes valiosos informes para su ordenamiento geográfico:

$1^{\circ}$ Repartimiento de Andahuaylas o repartimiento de Chancas del Valle:

A) Pueblo de Andahuaylas, doctrina, elevada ya a la categoría de villa. Sus ayllus: $I^{\circ}$ Yunga, con 37 tributarios originarios. II $^{\circ}$ Anansaya-Cuncataca, con 58 tributarios. III $^{\circ}$ Huaraca, con 34 IV $^{\circ}$ Yranec o Yañec, con 37. $\mathrm{V}^{\circ}$ Huachaca.

Pueblo de Quiñoaran: I el Ayllu Quiñoaran, con 20 tributarios originarios. $\mathrm{II}^{\circ} \mathrm{La}$ hacienda Capacalla con 6 tributarios.

B) La Asunción de Talavera: $\mathrm{I}^{\circ}$ «en la una banda del pueblo» los ayllus Anansaya con 49 tributarios; y $\mathrm{II}^{\circ}$ en la otra el ayllu Lurinsaya con 13 tributarios. III" «En la otra banda del pueblo, el ayllu Aranjuez con 89 tributarios. IV $^{\circ}$ El ayllu Cacacha con 69 tributarios. $\mathrm{V}^{\circ}$ Haciendas: Tarabamba, anexo de 
Talavera, con 15 tributarios; hacienda Pichapuquio con 12 tributaros; pueblo de Cascababa, anexo de Talavera, con 106 tributarios.

C) Pueblo y doctrina de San Jerónimo de Casana o Casania. Sus ayllus: $I^{\circ}$ Anansaya con 49 tributarios. II $^{\circ}$ Ayllu Lurinsaya con 69. III $^{\circ}$ Puna de Chuquicancha, con 2. IV ${ }^{\circ}$ Estancia de Argama con 2. Y hacienda La Laguna.

Pueblo de Pucucha, anexo de San Jerónimo. Sus haciendas: Cocharacau con 15 tributarios, Toczama con 13, Chuspibamba con 4, Antacachi y Bellavista con 8 .

Pueblo de Andarapa, anexo de San Jerónimo: Sus ayllus: $\mathrm{I}^{\circ}$ Anansaya y $\mathrm{II}^{\circ}$ Lurinsaya. III $^{\circ}$ Estancia de Caycabamba. IV $^{\circ}$ Haciendas de Huanqui, Chontaca, Cotahuacho, Humaca y Pacalla.

$2^{\circ}$ Reparimiento de Cayara

Pueblo de Nuestra Señora de Cocharcas, cabecera de doctrina, con 14 tributarios originarios.

Pueblo de Cayara, anexo, con 12 tributarios originarios.

Pueblo de Casabamba, con 4 tributarios originarios. Pueblo de Uranmarca, con 12 tributarios originaros.

Hacienda de Huancahuacho.

Pueblo de San José de Maranmoc, con 12 tributarios originarios.

Hacienda de Pariabamba, con 5 tributarios.

$3^{0}$ Repartimiento de Chincheros y Oripa, cabeza de doctrina:

Pueblo de San Juan de Chincheros, con 16 tributarios. La hacienda de Tayahuasi con 5 tributarios.

Pueblo de San Pedro de Uripa, anexo, con 196 originarios.

$4^{\circ}$ Repartimiento de Santiago de Ocobamba, cabeza de doctrina:

Pueblo de Ocobamba. Sus ayllus: Anansaya y Lurinsaya, los dos con 82 tributarios

Pueblo de Piscobamba, anexo, con 37 tributarios originarios. Sus haciendas: Socos con 10 tributarios, Ranracancha con 4, Carguayaco con 23. Sarahuarcay con 25, Condormarca con 2, Posocoy con 1, Sachapuna con 3, Casacancha con 3 y Picus con 13 (Barrionuevo - Piérola 1836: $137 \mathrm{r}-161 \mathrm{v})$.

Andahuaylas distaba de Chincheros 10 leguas, vencidas en un día de caminata (50 kilómetros / Fry 1889: 86).

\section{$5^{\circ}$ Repartimiento de Ongoy:}

Pueblo de Ongoy, cabeza de doctrina. Sus haciendas: Chacabamba con 32 tributarios originarios, Mozobamba con 23, Toruro con 2 y Pomachuco con 2 (Barrionuevo - Piérola 1836: 162r-179r).

$6^{\circ}$ Repartimiento de Chancas de las Punas:

A) Pueblo de La Concepción de Cachi, cabeza de doctrina, con 53 tributarios originarios.

Pueblo de Chullisana, anexo, con 25 tributarios originarios. Le pertenecía la

Hacienda de Tanquigua, con 48 habitantes (AGN. Contaduría 41: 178r).

Estancia de Yaurec con 8. Hacienda de Cascabambilla con 2.

Pueblo de Capca, anexo, con 47 tributarios originarios.

Sus haciendas: Cola con 8 originarios y Tanquigua con 4 forasteros.

B) Pueblo de Santiago de Huancaray, cabeza de doctrina, con 70 originarios.

Sus haciendas: Yuncaybamba, con 6 originarios; Mollepata con 1,

Pueblo de San Juan Evangelista, anexo Huáncaray, con 58 originarios.

Su hacienda de Cancayllo con 2 originarios.

Pueblo de San Juan Bautista de Turpo, anexo de Huancaray, con 21 originarios.

C) Pueblo de Guayana, cabeza de doctrina, con 10 originarios.

Pueblo de San Francisco de Chacrapampa, anexo, con 18 originarios.

Pueblo de San Francisco de Chiara, con 67 originarios.

D) Pueblo de San Cristóbal de Pampachiri, cabeza de doctrina.

Ayllu Mayo Anansaya con 70; ayllo Anta con 29.

Las estancias: Llatopampa con 7; Escahuaca con 1;

Huancacocha con 3.

Condorilla con 3; Concoma con 9.

Pueblo de Pomacocha, anexo, con 42 originarios.

Estancia de Huacollani, con 3.

Pueblo de Humamarca con 32 originarios.

Sus estancias: Puculluga con 1, y Huayllapucro con 1 (ibid: $179 \mathrm{v}-256 \mathrm{rr}$ ).

$7^{\circ}$ Repartimiento de Huancarama:

Pueblo de Huancarama, cabeza de doctrina. 


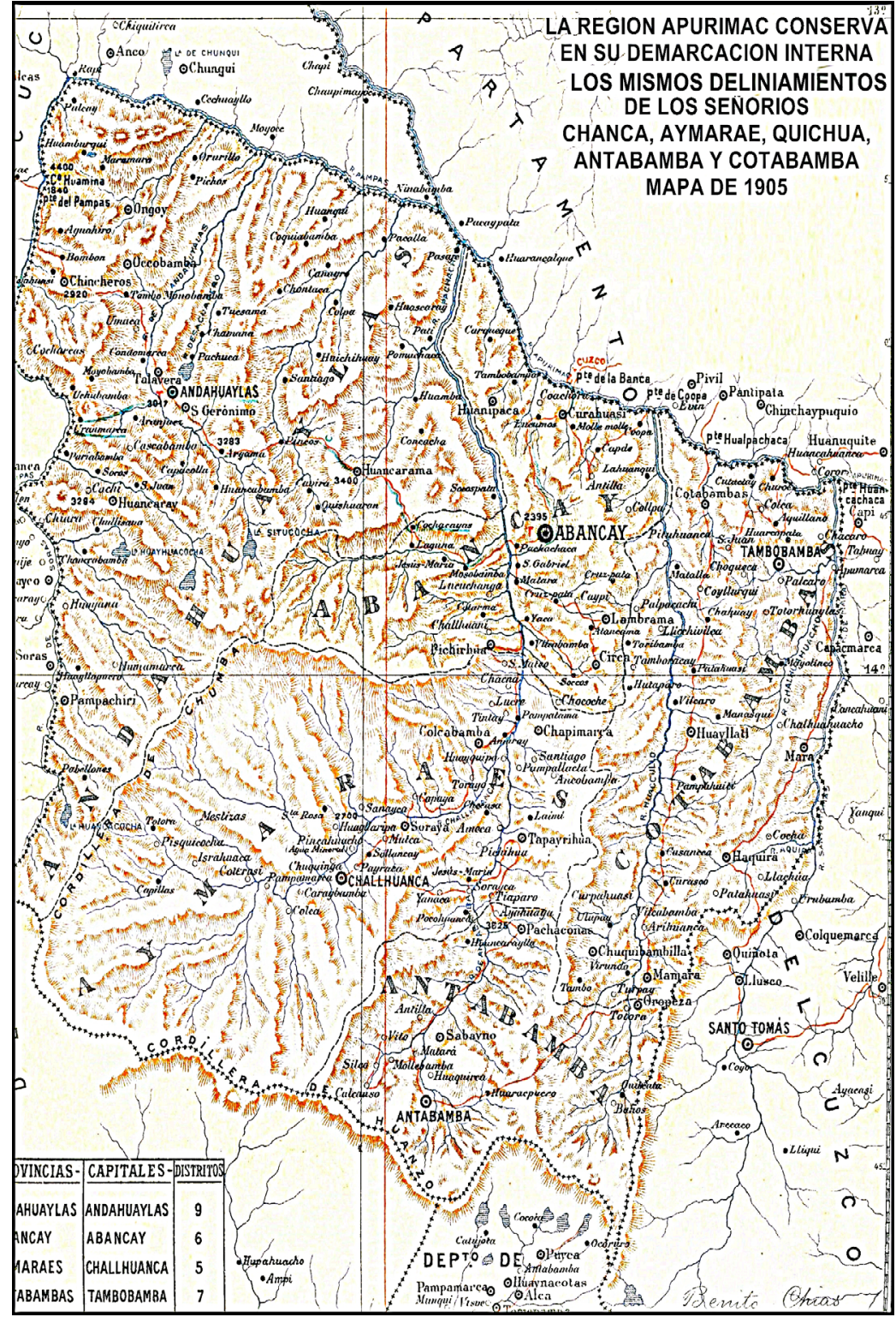

Sus ayllus: Sancosirca con 24 originarios; ayllu Quinua Guasaura con 13;

Ayllu Anco Curamba con 49; Ayllu Chachapoya con 22, y ayllu Paucar con 2.

Estancia de Matapuquio, con 19 originarios.

Haciendas Colpa con 32: Yaramay con 8; Santiago con 10; Pati con 3;

Pomachaca con 8; Carguacagua y Aguayuque con 1. Hacienda de Pincos y estancia de Caviro, las dos juntas con 3 originarios

Pueblo de Quishuara, anexo de Huancarama, con 27 originarios (Ibid: 256v - 290r. / Castro 1628 / Arce de Quiroz 1604: 40r, 42r, 42v, 48r / Rivero y Linaje 1714: 32r-35v. / Anónimo 1720-1739: 65 / Corregidores del Cusco 1732-1733: 249-
250, 255r-266r / AGN Contaduría Leg 41.- 1826: 148r, 157r, 148r-157r, 178r / BNL B14 .

En una aldea llamada Curamba, próxima a Zurite, provincia de Anta, donde se levanta un monumento antiguo (Stiglish 1922: 324), estaba el «repartimiento de Curamba», que por otro nombre le llamaban Cataguacho. La visita general arrojó 506 tributarios, 165 viejos, 720 muchachos y 1.753 mujeres. Total: 3.044 habitantes con seis curacas. Producían maíz, elaboraban ropa de awasca de hombre y mujer. Su tasa sumaba 2.500 pesos de plata al año (Miranda 1583b: 207).

Para completar este apartado, vamos a citar algunas referencias documentales concernientes a esta demarcación. En 1714 la provincia de Andahuaylas la Grande figura con 7 asentamientos poblados: 1 cinco pueblos: San Pedro de Andahuaylas, Ocobamba, Ongoy, Guancarama y Chinchero, más los dos asientos de San Jacinto de Chacabamba y pago de San Lorenzo de Moyobamba (Rivero y Linaje 1714: 32r-35v, 46r, 172r).

En 1732-1733 se apuntó que Andahuaylas la Grande tenía cinco repartimientos: "Partido del Valle», Ongoy, Juancarrama, Cayara y Paruro (sic). (Corregidores de los términos del Cuscco: 17321733: 249v-2504; 285r.266r).

Finalmente, en el censo de 1830 todavía se constata la vigencia del sistema de repartimientos. Respecto a la provincia de Andahuaylas, el empadronador oficial dejó un libro voluminoso, en cuyas páginas figuran:

$1^{\circ}$ Repartimiento de Andahuaylas, distante de Ayacucho 36 leguas. Sus ayllus: Yunga, Anansaya, Cuncataca, Guaraca, Cianeca y Huachaca. Pueblo de Quiñoaran. Hacienda Capaccalla.

$2^{\circ}$ Ayllu Anansaya de esta banda del pueblo de Talavera, distrito perteneciente al primer repartimiento. Ayllu Lurinsaya de esta banda. Ayllu Aranjuez de la otra banda del mismo pueblo de Talavera. Ayllu Ccacacha de la otra banda del mismo pueblo. Haciendas de Tarababa y Moyabamba. Pueblo de Cascabamba, anexo de Talavera.

$3^{\circ}$ Ayllu Anansaya del pueblo de San Jerónimo, doctrina de este nombre. Ayllus Anansaya y Lurinsaya. Pueblo de Pucucha. Haciendas de Argama, La Laguna, Cocharacan, Toczama, Chuspibamba. Y Chitacachi o Bellavista.

Pueblo de Andarapa, anexo de San Jerónimo. Ayllu Anansaya del pueblo anterior. Asiento de 
Cayabamba. Haciendas de Huanqui, Cotahuacho, Umaca y Pacalla.

$4^{\circ}$ Repartimiento de Cayara. Pueblo y doctrina de Nuestra Señora de Cocharcas. Pueblos de San Pedro de Cayara, Casabamba, Uchubamba, Yllanmarca y San Juan de Maraimoc, Haciendas de Huamanhuacho, Pariabamba y Tajahuari.

Pueblo de San Pedro de Uripa, anexo de Chincheros. Sus cuatro ayllus: Collana, Caihua, Chinchaysuyo y Mascca. Por ser pocos estaban ya unificados, no separados.

$5^{\circ}$ Repartimiento. Pueblo y doctrina de Santiago de Ocobamba. Ayllus Anansaya y Lurinsaya, ya unidos por ser de escasa gente. Pueblo de Piscobamba. Haciendas de Socos, Ranracancha, Carhuayaco y Sarahuacoy, Huayobamba, Cóndormarca, Posocoy, Sachapna, Caracancha y Picus.

$5^{\circ}$ Repartimiento, pueblo y doctrina de Ongoy. Haciendas Chacababa, Mozobamba, Pomachuco. Hato de Tururo.

$6^{\circ}$ Repartimiento. Pueblo y doctrina de Cachi. Pueblo de Chullisana. Estancia de Yauric. Haciendas de Cascabambilla.

Pueblo de Capaca, anexo de Cachi. Haciendas Cota y Tanquigua.

$7^{\circ}$ Repartimiento y doctrina de Santiago de Huancaray. Haciendas de Yuncaybamba y Mollepata. Pueblo de San Juan evagelista, anexo. Hacienda de Huancayllo. Pueblo de San Juan Bautista de Turpo.

$8^{\circ}$ Repartimiento de los Chancas de las Punas. Pueblo y doctrina de Guayana. Pueblo de San Miguel de Chocrampa, pueblo de San Francisco de Chiara.

$9^{\circ}$ Repartimiento de Chancas de las Punas. Pueblo y doctrina de San Cristóbal de Pampachiri. Sus ayllus: Amancaya, Anta del mismo pueblo. Estancias de LLatepampa, Escahuaca, Huancacocha, Condorillo y Conconia.

Pueblo de Pomacocha. Estancia de Huamallani. Pueblo de Humamarca, anexo de Pampachiri. Estancia de Pacollunga.

$10^{\circ}$ Repartimiento del pueblo y doctrina de Huancarama. Ayllu Sancoserca, Quichua-Huasaura del indicado pueblo. Ayllu Anco-Curamba. Ayllu Chachapoya. Ayllu Páucar del pueblo de Huancarama. Estancias de Matapuquio, Colpa, Yamachay, Páucar y su estancia de Cabira, Santiago, Pati, Pacchani, Pomachaca Carhuacachua y Aguanerque.
Pueblo de Quishuara, anexo del repartimiento de Huancarama (AGN. Lima. H4-1737).

\section{EL DOCUMENTO}

Cédula del marqués concediendo en depósito a

Diego Maldonado la encomienda de Ananchanca y

Urinchanca y otros pueblos más en las provincias de Chinchaysuyo, Collasuyo y Andesuyo

(Cuzco, 15 de abril de 1539)

El marqués don Francisco Pizarro, adelantado e capitán general e gouernador por Su Majestad en estos reinos de La Nueua Castilla llamada Pirú. \&. Hauiendo respecto que vos Diego Maldonado, vecino de la cibdad del Cuzco, sois uno de los primeros conquistadores destos reinos e que conmigo pasaron a la conquista e población dellos e que bien haueis servido a Su Majestad en la pacificación e conquista de los indios con vuestras armas y caballos a vuestra costa, padeciendo muchos trabajos e peligros. $\mathrm{Y}$ asimismo, siendo alcalde en esta dicha cibdad, servistes como persona celosa del seruicio de Su Majestad. E después os hallastes en el cerco desta cibdad y levantamiento que los indios hicieron. Y sservistes en todo, hasta tanto que la tierra se tornó a reducir al seruicio de $\mathrm{Su}$ Majestad, haciéndolo tan bien como todo hijodalgo lo debe hacer.

E porque es bien que seais por vuestros servicios ratificado, en nombre de Su Majestad vos deposito, según que agora lo habeis tenido e poseído, y hasta tanto que se hace el repartimiento general, el cacique prencipal de Andaguaylas con todos sus caciques e prencipales que son en Hananchangais y Orinchanga, con los quichuas de Cilcapoco, que son los siguientes:

- Chuquicondor Lapa, señor del pueblo de Sayoguacho.

- Y otro que se dice Lombo, señor del pueblo de Pomiguancho.

- Y otro que se dice Condor Suca, señor del pueblo Guamamylla.

- Y otro que se llama Asto, señor del pueblo Capacalla.

- Y otro que se dice Llacta Conas, señor del pueblo Oncoro.

- Y otro que se dice Guasco, señor del pueblo de Bambamalca.

- Y otro que se dice Guncho, señor del pueblo Guevilla 
- Y otro que se dice Dulcaguaman, señor del pueblo Ercacha.

- Y otro que se dice Tomay y Nanpa, señor del pueblo Guayapo.

- Y otro que se dice Maras Guama, señor del pueblo Eaque e Amares. Es Inga.

- Y otro que se dice Orozo, señor de Guayaonillo. (Es) Chachapoya.

- Y otro que se dice Pocovillca, señor de Pacocha.

- Y otro que se dice Yanas, señor del pueblo Guatara.

- E otro que se dice Sutaya, señor del pueblo Oramarca.

- E otro que se dice Allauca, señor del pueblo Yslana.

- Y otro que se dice Coyca, otro Mayma, señor del pueblo Pocollo, son quichuas.

- Y otro que se dice Guaman Vilca, señor del pueblo Gualgayo.

- Y otro que se dice Tubianaypa, señor del pueblo Cochabamba.

- Y otro que se dice Albruca, señor de pueblo Chuquibamba.

- Y otro que se dice Chochuma, señor del pueblo Gurullana // Son quichuas.

- Y otro que se dice Apaca, señor de pueblo de Cocas. Son yungas.

- Y otro que se dice Cancacha, señor de Sillueque.

- Y otro que se dice Canas señor de Yanama.

- Y otro que se dice Ynda, señor de Totora. Son quichuas.

- Y otro que se dice Navi Hasto, señor del pueblo de Aymayba.

- Y otro que se dice Suca, señor Chuchumb.

- Y otro que se dice Guamamlapa, señor del pueblo de Bambamalca.

- Y otro que se dice Guaraca, señor del pueblo de Chopalla.

- Y oro que se dice Guasco, señor del pueblo de Queca.

- Y otro que se de Qullichanchas, señor del pueblo de Llamay.

- Y otro que se dice Naupa Condor. Señor del pueblo de Chupuis Guacho.

- Y otro que se dice Guachaca, señor del pueblo de Pupuca.

- Y otro que se dice Magula, señor de Pomachaca.

- Y otro Curytomay, y otro que se dice Tomay Condor, señores de Midapa.

- Y otro que se dice Llangare, señor del pueblo de Quenoavilla.
- Y tro que se dice Queque Hasto, señor del pueblo de Laracalla.

- Y otro que se dice Llacaguavis, señor del pueblo de Opibacho.

- Y otro que se dice Guasco Pachua, señor del pueblo de Tulpo.

- Y otro que se dice Chuquillapar, señor del pueblo Midaquecua.

- Y otro que se dice Ala, señor del pueblo Ococho.

- Y otro que se dice Quiquimalca, señor del pueblo Tiquillo.

- Y otro que se dice Maqui, señor del pueblo Magua y Camalla.

- Y otro que se dice Quiqui, señor del pueblo de Caci.

- Y otro que se dice Viscasasa, señor del pueblo de Chilicani.

- Y otro que se dice Sulla señor del pueblo de Capicalli.

- Y otro que se dice Chocollo, señor del pueblo Gola.

- Y otro que se dice Lapacho, señor del pueblo Chuquillanca

- Y otro que se dice Qullucha, señor del pueblo de Aychica.

- Y otro que se dice Suca, señor del pueblo Chiara.

- Y otro que se dice Guacho, señor del pueblo de Paravaya.

- Y otro que se dice Guasco, señor del pueblo de Paracaya.

- Y otro que se dice Chuaco, señor del pueblo de Chacana.

- Y otro que se dice Hasto y otro Lapa, señores del pueblo Coroya.

- Y otro Changa Guasca, señor del pueblo Suya.

- Y otro que se dice Curosica, señor del pueblo Yanapiaco.

- Y otro que se dice Guacharondo y Magula, seńores del pueblo Chunllanga.

- Y otro que se dice Chuquicamaoa, señor del pueblo de Guayana.

- Y otro que se dice Sibo Páucar, señor del pueblo Omamarca. Son orejones.

- Y otro que se dice Calvacuri y otro que se dice Sevum, señores del pueblo Vilcabamba.

- Y otro que se dice Moygua, señor del pueblo Alcaraycay. Es orejón.

- Y otro que se dice Toca, señor del pueblo Patubi. 
- Y otro que se dice Ahoca Sibi, señor del pueblo Chuca. Es orejón.

- Y otro que se dice Guachaca y su pueblo Aymaras, que son mitimaes de los Aymaras, que se dice Soso.

- E otro que se dice Chauca Quiyaruro y otro que se dice Tucuyrico, que se llama Horcoguaranga, es orejón, señores de pueblo de Mayamarca y Canibamba.

- Y ansimiesmo os deposito en la provincia de Chinchaysuyo el cacique Cayo Yupanqu, señor del pueblo Parco.

- E otro prencipal del dicho pueblo de Parco, que se dice Mazozo.

- E otro que se dice Mayta Yupanqui y otro Callacana, seńores de pueblo Patete.

- Y otro prencipal que se dice Chuquillanqui, que es guanca, y otro que se llama Cubilica, que es yauyo, señores del pueblo Guancabanba.

- Y otro que se dice Guamancagua, señor del pueblo Quebancha.

- Y otro que se dice Guaraca, señor del pueblo Yanaca, son chancas, con las mamaconas e indios yungas de Sóndor, que son en Limatambo con ciento cincuenta indios.

- Y más los deposito en la prouincia de Collasuyo el cacique Pariguana, señor del pueblo de Guaman.

- Y otro principal que se dice Páucar, señor del pueblo de Guáscarquiguar.

- E otro que se llama Vichocamache, señor del pueblo Picoy.

- E otro que se dice Yana Yangue, señor del pueblo Coras.

- E otro prencipal que se dice Ococha, señor de pueblo de Quiepe.

- E otro que se llama Harosco, señor del pueblo de Marpa.

- E otro que se llama Paro, señor del pueblo Soyba. Con doscientos y sesenta indios de los mitimaes sus subjetos wue le hace comida doquier que estén.

- Y asimiesmo seos deposita en la prouincia de Andesuyo cuarenta indios en la mitad de los pueblos de Omachondal, y el prencipal de Matoalpa.

- Y otro que se dice Pomamalca.

- Y otro prencipal que se dice Sulcanavi, señor del pueblo Oyomayo, con los caciques que agora son o de aquí adelante fueron, porque la otra mitad están depositados en Pedro de los Ríos.
Todos los cuales dichos caciqes e pueblos e prencipales que agora son o de aquí en adelamte fueren subjetos al dicho Andaguaylas y a los otros demás caiques contenidos en esta cédula, para que déllos os sirváis conforme a los mandamientos reales, con tanto que dejéis a los caciques sus mujeres e hijos e los otros indios para su servicio como Su Majestad manda.

Fecha a quince días del mes de abril de mil e quinientos e treinta e nueue ańos. El Marquez.

(AGI, Patronato 93.- Sevilla).

\section{Referencias bibliográficas}

Acosta, José de [1590] 1954. Historia natural y moral de Las Indias. BAE. Madrid.

Albornoz, Cristóbal de [1582] (1967. «Instrucción para descubrir todas las huacas del Pirú y sus camayos y haciendas». Journal de la Societé des Americanistes. París. T. LVI.

Arce, Alonso de. 1604. «Descripción de la gobernación de Guayaquil, en lo natural» CDIA, IX: 247 - 309.

Arriaga, Pablo José de [1621] 1920. Extirpación de la idolatría en el Perú. CLDHP. 2da. Serie 1. Lima 1920.

Bertonio, Ludovico. 1612. Vocabulario de la Lengua aymara [...]. Impreso en la casa de la Compañía de Juli pueblo en la provincia de Chucuito. Por Francisco del Canto (Primera y segunda parte)

Betanzos, Juan de [1551]) 1987. Suma y narración de los incas. Edición de M. del C. Martín Rubio. Madrid.

Brooks, William E. / Luisa Vetter Parodi. 2012. «Antigua fundición de plomo en el sitio inca de Curamba, departamento de Apurímac, Perú». BIFEA 41-2. Lima.

Bueno, Cosme (1754-1878).1878. («Descripción de los obispados pertenecientes al virreinato del Perú»). DOLIP. III Lima..

Cabello Balboa, Miguel. [1586] 1951 Miscelánea antártica. Una Historia del Perú

Cabredo. P. Rodrigo de. 1600 «Annua de la provincia del Perú por el año de 600 pa nuestro Padre General». MP. VII. Roma.

Calancha, Antonio de la 1638. Coránica moralizada de la orden de San Agustín en el Perú. Barcelona

Calvete de Estrella, Juan Cristóbal [1567]) 1964. Rebelión de Pizarra en el Perú, y vida de don Pedro Gasea. BAE. Madrid.

Cieza de León, Pedro de (1553). Parte primera de la crónica del Perú. Sevilla. Con privilegio real. 
Сово, Bernabé. ([1653] 1964). Historia del Nuevo Mundo. BAE. Dos volúmenes. Madrid.

Del Prado, Juan ([1613] 1919) «Misión de las provincias de Huachos y Yauyos». RH. Tomo 63).

Espinoza Soriano, Waldemar (1987). Los incas, economía, sociedad y Estado en la era del Tahuantinsuyo. Amaru Editores. Lima.

Garcilaso de la Vega, Inca ([1609] 1963). Primera parte de los comentarios reales de los incas. BAE. Madrid.

GonZÁlez CARrÉ (2002). Los incas y sus contemporáneos. La sierra central, 1000-1500 D.C. EHLA; II. Lima.

Guaman Poma de Ayala, Felipe ([1615] 1936). Nueva coránica y buen gobierno. París. Institut D’Etnologie.

Gutiérrez de Santa Clara, Pedro ([1550] 1963). Quincenarios o historia de las guerras civiles del Perú (15441548) y de otros sucesos de Las Indias. Madrid: BAE.

Las CaSas, Bartolomé de ([1561] 1909). Apologética historia de Las Indias. Madrid: NBAE.

LizÁrRaga, Reginaldo de ([1605] 1909). Descripción breve de toda la tierra del Perú, Tucumán, Rio de La Plata y Chile. NBAE. 15. Madrid.

López de Caravantes, Francisco ([1630] 1986). Noticias del Perú. BAE. Madrid. 1985.

López de Gómara, Francisco ([1552] 1946). Hispania Victrix. Primera y segunda parte de la historia general de Las Indias. BAE. Madrid.

Mendoza, Diego de (1664). Chronica de la provincia de S. Antonio de Los Charcas del Orden de Ntro. Seraphico P. S. Francisco [...] Matriti.

Miranda, Cristóbal de ([1583b] 1975). Tasa de la visita general de Francisco de Toledo (...). UNMSM. Lima.
Miranda, Cristóbal de ([1583a] 1925). Relación de los oficios que se proveen en el reino del Perú, de las personas que los confieren y de los salarios asignados a ellos. Años 15721583. GPCP. IX. Madrid.

Montesinos, Femando de ([1642] 1930). Memorias antiguas, historiales y politicas del Perú. CLDRHP, VIL $2^{2}$ serie. Lima.

Murúa, Martín de [1616]. Historia general del Perú, origen $y$ descendencia de los incas [...] Introducción y notas de Manuel Ballesteros - Gaibrois. Madrid, MCMLXII. Dos volúmenes.

Palomino, Diego ([1549] 1897). Relación de las provincias que hay en la conquista del Chuquimayo que yo el capitán... tengo por Su Majestad y por «el muy Ilustre Señor Pedro Gasca presidente de la Audiencia Real de estos Reynos del Perú por Su Majestad. RGI: 1897; IV.

Paz Soldán, Mariano Felipe (1877). Diccionario geográfico estadístico del Perú. Lima. Imprenta del Estado.

Polo de Ondegardo, Juan ([1561] 1817). Informaciones acerca de la religión y gobierno de los incas. Colección Urteaga-Romero. Lima 1917.

Ribera de Chávez (1586), I: $203 / 1965$

Sarmiento de Gamboa, Pedro ([1572] 1960). Historia índica. BAE. Madrid.

Stiglich, Germán (1922). Diccionario geográfico del Perú [...] Imprenta Torres Aguirre. Lima. Tres volúmenes.

Vaca de Castro, Cristóbal (1543). «Ordenanzas de tambos. Distancias de unos a otros, modo de cargar los indios y obligaciones de las justicias [...]». RH. III - IV: 427- 492. 